\author{
AleKsander Posern-ZielińsKi \\ Uniwersytet im. Adama Mickiewicza w Poznaniu \\ Polska Akademia Nauk
}

\title{
Szczęśliwy traf i tubylczy partner w badaniach terenowych. Z doświadczeń antropologa w USA i Ameryce Południowej
}

\section{Refleksje wstępne}

$\mathrm{N}$ awiązując do dość metaforycznego tytułu tego szkicu, chciałbym zapowiedzieć, iż dwoma przewodnimi wątkami poniższych refleksji, wynikających z osobistych doświadczeń antropologa i amerykanisty, są po pierwsze - nieprzewidziane, nieplanowane wydarzenia i spotkania określane najczęściej mianem „szczęśliwego trafu” oraz po drugie - zalety wynikające ze współpracy terenowej $\mathrm{z}$ ",tubylczym" partnerem/asystentem posiadającym kompetencje w zakresie nauk społecznych. Na znaczenie tych kwestii wskazuję, odwołując się do moich doświadczeń terenowych z badań etnograficznych prowadzonych w Stanach Zjednoczonych wśród Polonii oraz w Ameryce Południowej w środowiskach indiańskich (Ekwador, Boliwia, Chile). Oba te wątki (szczęśliwy traf i znaczenie tubylczego asystenta) splotły się szczególnie mocno w czasie prac realizowanych wśród Mapuczy na terenie Araukanii (płd. Chile). Mam nadzieję, że poruszone tu zagadnienia okażą się nie tylko interesującą relacją z badań terenowych prowadzonych na obszarze obu Ameryk, ale będą również pobudzać do refleksji i dostarczać pożytecznej inspiracji ${ }^{1}$.

\footnotetext{
${ }^{1}$ Refleksje te dotyczą przede wszystkim badań realizowanych w latach 2008-2011 w Chile, w ramach projektu „Araukania i jej mieszkańcy w 160 lat po Ignacym Domeyce”, który finansowany był ze środków MNiSzW.
} 
Etnograficzne badania terenowe w każdym z okresów rozwoju antropologii mają swoją specyfikę, która wynika co najmniej z trzech czynników. Po pierwsze są one dostosowane do klimatu (ducha) epoki, w której prowadzą swą działalność badacze oraz do sytuacji, w jakiej znajdują się społeczności będące w centrum ich zainteresowania. Inny charakter miały one w czasach kolonialnych, w odmienny sposób realizowano je w dobie kształtowania się państw narodowych, a całkiem inaczej praktykujemy te badania w dobie globalizacji. Drugim ważnym czynnikiem decydującym o specyfice tychże badań są zmieniające się w obrębie samej antropologii podejścia teoretyczne i strategie preferowanych metod terenowych. Jak doskonale wiemy, te narzędzia interpretacyjne ewoluowały wraz ze zmianą naukowych paradygmatów, przechodząc od fazy dokumentacyjnej „etno-grafii” i/lub „ludo-znawstwa” do prób holistycznego ujmowania kultury w jej strukturalnej i procesualnej złożoności, by wreszcie dojść do refleksji nad sposobami konceptualizacji świata dokonywanymi przez samych "tubylców”. Wreszcie trzeci istotny element, warunkujący charakter prowadzonych w terenie badań empirycznych stanowi (nadal) dychotomia lokalizacyjna, której wynikiem stał się klasyczny podział na „etnografię krajową”, ludoznawstwo, niemieckie „Volkskunde” czy współczesną „etnologię europejską” z jednej strony oraz z drugiej na „etnografię powszechną", „Völkerkunde” czy (post)kolonialną antropologię społeczną/kulturową skupioną na studiach nad odległymi kulturami i społecznościami pozaeuropejskimi.

Obecnie podziały te ulegają stopniowemu zanikowi, szczególnie w aspekcie warsztatowym i interpretacyjnym. Nadal jednak odczuwana jest silna bariera między terenem bardziej bliskim badaczowi, swojskim dla jego kulturowej percepcji, lepiej zrozumiałym w znaczeniu ontologicznym a tym odległym obszarem badawczym, zwanym niegdyś „egzotycznym”, którego mieszkańcy są dziedzicami odmiennego kręgu kulturowego/cywilizacyjnego, żyją w zdecydowanie innych warunkach i posługują się nieznanymi bliżej badaczowi kategoriami. Prowadzenie tego rodzaju badań, począwszy od logistyki, a skończywszy na wysiłkach zrozumienia zasad funkcjonowania „obcego” społeczeństwa, jest zawsze dla antropologa wielkim wyzwaniem i to zarówno naukowym, jak i egzystencjalnym. Im większy napotyka dystans kulturowy (widoczny w obrębie wartości, norm, zasad, koncepcji itp.), oddzielający go od własnej cywilizacyjnej ekumeny, tym bardziej piętrzą się przed nim trudności w pokonywaniu wyłaniających się barier poznawczych.

$\mathrm{Z}$ pewnością jedną z najlepszych strategii rozwiązujących ten problem jest poświęcenie długiego okresu czasu na dobre rozpoznanie nieznanego otoczenia. W tym zakresie nową jakość do antropologii niewątpliwie w prowadził Bronisław Malinowski, pokazując swym osobistym doświadczeniem, jak efektywne mogą być obserwacje etnograficzne prowadzone w sposób systematyczny i to przez wiele miesięcy ${ }^{2}$. Od tego czasu w antropologicznej praktyce upowszechniła się

2 Zalety tego podejścia, w oparciu o własne doświadczenia, B. Malinowski niezwykle trafnie sformułował we Wprowadzeniu do Argonautów zachodniego Pacyfiku (Malinowski 1981: 27-58). 
strategia prowadzenia wielomiesięcznych badań, umożliwiających "głębokie" poznanie otoczenia i dających szansę na uzyskanie wartościowych materiałów, które pozwalają lepiej zrozumieć "obcy” świat społeczny. W niektórych przypadkach czas pobytu w środowisku "tubylczym" przedłużał się i trwał nawet kilka lat, szczególnie wówczas, kiedy to badacz/antropolog pełnił jednocześnie w tym "obcym" dla siebie otoczeniu funkcję reprezentanta/agenta "zachodniego" świata. Myślę tu o kolonialnych urzędnikach, wojskowych, przedstawicielach administracji państwowej, pracownikach NGO-sów (organizacji pozarządowych i pomocowych) czy wreszcie o misjonarzach. Dzieje aktywności tych ostatnich, począwszy co najmniej od XVI w., wskazują na to, że znajdowali się wśród nich nie tylko ewangelizatorzy, ale także wybitni antropologowie studiujący z uwagą tubylcze kultury. Jednym z nich był profesor Wojciech Bęben, który na obszarach Nowej Gwinei i pobliskich wysp (Cieśnina Torresa) spędził kilkadziesiąt lat, poświęcając się głównie zgłębianiu "tajemnic" życia codziennego tamtejszych rdzennych mieszkańców ${ }^{3}$. Sądzę, że poza mało znanym (niestety) Janem Kubarym, profesjonalnym agentem etnomuzealnym, który większość swego dorosłego życia spędził na atolach Mikronezji ${ }^{4}$, nie ma wśród polskich etnologów badacza z tak imponującym stażem i doświadczeniem terenowym.

Wracając jednak do głównego nurtu rozważań, należy nadmienić, iż poza czynnikiem czasu poświęconego na zgłębianie kultury "obcego" etnosu istotnym elementem współdecydującym o sukcesie badawczym jest charakter relacji łączących w terenie antropologa ze społecznością, wśród której przebywa i której kulturę zamierza poznać. Jeśli odwołamy się do historii antropologii, to spostrzeżemy, że spectrum tych wzajemnych stosunków było niezwykle bogate i zróżnicowane. Nie miejsce tu, aby temu zagadnieniu poświęcać szczególną uwagę, ale warto co najmniej wspomnieć o trzech "modelach” tego rodzaju relacji. Pierwszy z nich dotyczy sytuacji, w której samotny antropolog dociera do „swej” społeczności i żyjąc czas jakiś wśród niej, stara się zebrać jak najwięcej informacji potrzebnych mu ze względu na realizowany temat badań. Drugi model, nazwijmy go „kooperacyjnym”, obejmuje takie sytuacje, kiedy to antropolog ściśle współpracuje z kilkoma wybranymi członkami tubylczej społeczności (wodzem, szamanem, lokalnym autorytetem), którzy faktycznie współuczestniczą w procesie pozyskiwania etnograficznych danych i dzięki swym fachowym konsultacjom ułatwiają badaczowi „zrozumienie” otaczającej go rzeczywistości. W wielu monografiach etnograficznych znajdujemy potwierdzenie takiej praktyki, często wzmocnione autorskimi wyrazami podziękowania za istotny wkład tych "tubylczych" informatorów w opracowane dzieło.

Wreszcie mamy także do czynienia z trzecim wariantem, któremu poświęcony jest w dużej mierze niniejszy artykuł. Myślę tu o takiej sytuacji terenowej,

\footnotetext{
${ }^{3}$ Wyjątkowy rodzaj doświadczeń etnograficznych tego badacza na terenie Oceanii uwypuklił L. Mróz w recenzji książki W. Bębna, Dzieci kazuara (2006: 494), zamieszczonej w posłowiu tej samej pracy.

${ }_{4}^{4}$ Zob. Wypych, K. (1969). W cieniu fe. Śladami Jana Stanistawa Kubarego. Wrocław: Polskie Towarzystwo Ludoznawcze.
} 
w której stroną aktywną jest nie tylko badacz przybyły z „innego świata”, ale także jego profesjonalny partner lokalny, ściśle współpracujący z zagranicznym antropologiem. Taki „tubylczy asystent” jest cennym towarzyszem w trakcie badań, jeśli dobrze orientuje się w miejscowych realiach kulturowych. Jego znaczenie wzrasta wydatnie, gdy okazuje się, że potrafi on dodatkowo wykorzystać swe rodzime sieci społeczne w celu skutecznego dotarcia do ważnych informatorów. Jeśli ponadto dysponuje on kompetencjami w zakresie prowadzenia prac terenowych i posiada „wyczucie” antropologiczne, wówczas staje się bezcennym uczestnikiem badań, umożliwiającym (do pewnego stopnia) przezwyciężanie naturalnych sprzeczności wynikających z dwoistości perspektyw - emic i etic. Wymienione wyżej strategie badawcze nie tworzą alternatywnych czy nawzajem wykluczających się scenariuszy; są zazwyczaj stosowane w zależności od konkretnej sytuacji, planowanych celów i możliwości pracy w terenie. Z pewnością model „partnerski” zyskuje obecnie coraz większe uznanie, szczególnie w tych krajach i regionach, w których dzięki postępom wyższej edukacji coraz łatwiej spotkać można miejscowego/tubylczego antropologa czy socjologa. Na osobiste doświadczenia wynikające z pracy w takim interetnicznym "tandemie” zwrócę uwagę nieco dalej, po omówieniu kwestii związanych z logistyką badań terenowych, których przebieg jest często wypadkową planowanych założeń i nieprzewidzianych w żadnym scenariuszu wydarzeń.

\section{Wydarzenia przypadkowe w terenie i ich znaczenie}

Poza egzystencjalnymi aspektami prowadzenia badań terenowych, wynikającymi z osobowości badacza, charakteru jego relacji z „tubylcami” i profesjonalnych doświadczeń antropologa zdobytych w trakcie wcześniejszych interkulturowych spotkań, prace te kształtowane są jeszcze przez co najmniej dwa ważne czynniki. Pierwszy z nich polega na zaplanowaniu całego badawczego przedsięwzięcia, poczynając od „banalnej” strony logistycznej, a kończąc na wyborze odpowiednich narzędzi, umożliwiających efektywne zdobywanie danych etnograficznych przewidzianych w założeniach projektu. Jednakże gdy już pojawimy się w wybranym "terenie”, to nasze "metodycznie” opracowane plany zderzają się często z dynamicznie zmienną i trudną do przewidzenia sytuacją, w jakiej antropologowi przychodzi działać. Wówczas powinien on reagować elastycznie na te wydarzenia i starać się do nich dostosować. Może także wykorzystać nowe (często wyjątkowe) okoliczności do modyfikacji planu swych zamierzeń i włączyć obserwacje nieoczekiwanych sytuacji do swego badawczego curriculum. Wśród wielu niemożliwych do przewidzenia, ale „obiektywnych" okoliczności - choćby takich, jak rebelie, bunty, strajki, kataklizmy, lokalne konflikty itp. - napotkać można również w terenie na szereg niespodziewanych sytuacji dotykających przede wszystkim samego badacza. Myślę tu o roli przypadku, który, tak jak i w naszym całym życiu, występuje również w trakcie prowadzenia badań terenowych i może mieć spore znaczenie. Tego rodzaju 
przypadki dotyczyć mogą sytuacji badacza (korzystnej lub zgoła fatalnej), który pojawia się w "swej" społeczności w momencie dla niej przełomowym, w czasie lokalnego kryzysu czy okresu pełnego napięć. Obok przypadków wynikających z trajektorii czasu, także i miejsce penetracji etnograficznych okazać się może nieoczekiwanym źródłem nieplanowanych, a niezwykle interesujących obserwacji, rejestrujących np. konflikty klanowe, napięcia religijne czy działania o charakterze modernizacyjnym. Ważnym elementem przynależnym do kategorii „przypadku” mogą być spotkania z nieznanymi wcześniej osobami, których bliższe poznanie okazuje się $\mathrm{w}$ konsekwencji istotne lub bardzo pomocne $\mathrm{w}$ procesie pozyskiwania wartościowych danych terenowych. Jest rzeczą oczywistą, że wszystkie tego rodzaju „przypadki” mogą mieć dla badacza i jego projektu zarówno wymiar pozytywny, jak i negatywny. Raz będą zdecydowanie ułatwiały mu zadania, ale mogą również przyczynić się do pojawienia się nieoczekiwanych trudności. Ten pierwszy aspekt, częściej spotykany na mojej drodze, uznany być może za przysłowiowy „łut szczęścia”, który pozwala badaczowi na niestandardowe usytuowanie swej pozycji obserwacyjnej i pozyskanie dzięki temu wnikliwego oglądu często dość wyjątkowych wydarzeń. $Z$ drugiej strony zdarzenia o "negatywnej” konotacji mogą w skrajnych przypadkach uniemożliwić kontynuację badań, drastycznie ograniczyć możliwości poruszania się po terenie czy poważnie zakłócić wysiłki na rzecz budowy relacji zaufania pomiędzy antropologiem a lokalną społecznością.

A zatem możemy stwierdzić, że powodzenie w procesie zdobywania satysfakcjonujących danych $w$ trakcie prowadzenia badań terenowych jest wypadkową co najmniej trzech istotnych czynników. Pierwszym byłby splot czynników subiektywnych, związanych z osobowością i kompetencją zawodową samego badacza. Drugi uwarunkowany jest silnie czynnikami obiektywnymi, a więc niezależną od woli badacza i jego strategii postępowania zastaną sytuacją $\mathrm{w}$ terenie $\mathrm{w}$ momencie podejmowania obserwacji. Wreszcie trzecim są trudne do przewidzenia i planowania wydarzenia o charakterze "przypadkowym", które wprawdzie mogą mieć niewielkie znaczenie dla pracy antropologa, jednak czasami ich oddziaływania wykazują znaczący wpływ na przebieg pracy terenowej i jej rezultaty.

Znów odwołując się do wieloletnich własnych doświadczeń, mogę przytoczyć kilka dość charakterystycznych przykładów, które wskazują na rolę wspomnianych wyżej „przypadków” dotyczących zarówno wyboru miejsca badań, momentu, w jakim były one realizowane, jak i charakteru kontaktu z miejscową społecznością. Wszystkie te trudne do przewidzenia "przypadki” dotyczyć mogą tylko jednego z wymienionych wyżej elementów, choć zazwyczaj łączą się ze sobą, tworząc zespół korzystnych lub niepomyślnych uwarunkowań. Jeśli chodzi o czynnik „miejsca” (czyli terenu badań), to zwykle określamy go w pewnym przybliżeniu, wyznaczając jako nasz cel (target) konkretną grupę etniczną/ lokalną, region, okolicę, zespół osad itp., nie mając u progu empirycznych badań dobrej orientacji co do tego, czy dokonany wybór był optymalny i sprzyjał nawiązaniu dobrych kontaktów z miejscową społecznością. Brak wcześniejszych 
rekomendacji, wskazówek czy osobistego rozeznania może zostać zrekompensowany "szczęśliwym trafem".

Przykładem tego rodzaju były moje doświadczenia $\mathrm{w}$ trakcie badań prowadzonych w Stanach Zjednoczonych, z zamiarem głębszego poznania realiów życia tamtejszej Polonii ${ }^{5}$. Po przybyciu do Minneapolis (w roku 1992), rozpocząłem poszukiwania kwatery na cały rok zaplanowanego pobytu, kierując się dogodną lokalizacją, niezbyt odległą od uniwersytetu oraz, co oczywiste, wysokością czynszu. Dość szybko natrafiłem na odpowiadającą moim oczekiwaniom ofertę. Szczęśliwym trafem okazało się, że wraz z wynajętym mieszkaniem znalazłem się w samym sercu historycznej dzielnicy słowiańskich imigrantów (Polaków, Słowaków, Ukraińców, Rusinów Karpackich) i do tego w bliskim sąsiedztwie tzw. „polskiej" parafii. Niedzielna wizyta w kościele przyniosła kolejne szczęśliwe wydarzenie, bowiem jeden $\mathrm{z}$ rezydujących tam księży okazał się chrystusowcem, tj. kapłanem przynależącym do Towarzystwa Chrystusowego dla Polonii Zagranicznej (SVD), a więc zgromadzenia, którego Wyższe Seminarium od lat funkcjonuje w Poznaniu i w którym to przez czas jakiś byłem "dochodzącym" wykładowcą, zapoznającym studentów z problematyką życia wspólnot polonijnych. Ten „zawodowy” szczegół biograficzny, a także - jak przypuszczam - rekomendacje z głównej siedziby Zgromadzenia, sprawiły, że w niezwykle krótkim czasie stałem się częścią tamtejszej wspólnoty polonijnej, która przyjęła mnie z pełnym zaufaniem i niezwykłą otwartością.

Niebawem okazało się, że znalazłem się również w centrum narastającego konfliktu zachodzącego pomiędzy „starą" Polonią (w zasadzie Amerykanami polskiego pochodzenia) a nowymi przybyszami, wywodzącymi się z fali emigracji solidarnościowej lat 80 . XX w. Moja pozycja osoby „neutralnej”, posiadającej status ",specjalisty od spraw Polonii", a jednocześnie obdarzonej zaufaniem członków parafii, sprawiła, że w pewnym momencie zostałem wybrany na członka delegacji (w roli tzw. eksperta) do biskupa zarządzającego diecezją, aby przy jego wstawiennictwie rozładować zaistniałe napięcia. Był to splot wyjątkowo korzystnych dla badacza wydarzeń, który z jednej strony kapitalnie ułatwił rozpoznanie roli i znaczenia parafii w życiu amerykańskiej Polonii, z drugiej jednak sprawił, że część niezwykle interesujących obserwacji i materiałów dotyczących źródeł i natury wewnętrznych konfliktów w obrębie środowiska polonijnego nie mogła zostać przez czas jakiś po powrocie do kraju wykorzystana "naukowo" w formie antropologicznej analizy ${ }^{6}$. Ważną przeszkodą były oczywiście względy etyczne i zbyt zażyłe relacje z bohaterami tych wydarzeń. Mogliby mieć oni uzasadnione pretensje wobec ujawnienia ich roli w konkretnym jednostkowym konflikcie, mającym jednak dla badacza wymiar zdecydowanie ogólny, ukazujący bowiem przede wszystkim dominujące tendencje w życiu imigrantów, związane z ich tożsamością, orientacją kulturową i stosunkiem do polonijnych instytucji.

\footnotetext{
${ }_{5}^{5}$ Badania te miały być kontynuacją wcześniejszych studiów o bardziej ogólnym charakterze: zob. Posern-Zieliński 1982.

${ }^{6}$ Nieco więcej na ten temat: zob. Posern-Zieliński (2003: 49-62).
} 
Zdarzenia mieszczące się w sferze sygnalizowanych tu „przypadków” zapisały się również $\mathrm{w}$ rejestrze moich doświadczeń etnograficznych w trakcie badań prowadzonych w Ameryce Południowej. Z perspektywy lat widzę wyraźnie, że pewne sytuacje i momenty, $w$ jakich znalazłem się $w$ terenie, miały wielkie, a czasami nawet decydujące, znaczenie dla poznania istoty zachodzących przemian. Jedna z takich sytuacji wydarzyła się we wczesnych latach 90 . XX w. w Ekwadorze. Realizowane wówczas projekty antropologiczne zaprowadziły mnie do Otavalo, niewielkiego miasta położonego na północ od Quito, słynącego $\mathrm{z}$ organizowanych tam targów rękodzieła regionalnego, wytwarzanego przez lokalnych Indian (z grupy Kiczua), manifestujących bardzo otwarcie swą tubylczą tożsamość. Były to lata znaczących w Ekwadorze ruchów etnicznego aktywizmu, który przejawiał się nie tylko w sferze społecznej i politycznej, ale widoczny był również w przestrzeni symbolicznej. W Otavalo interetniczny konflikt przybrał wówczas formę „,walki” o symbole, ujawniając swą dynamikę w trakcie dorocznego regionalnego święta znanego pod nazwą „Fiesta del Yamor”, w którym to główną, a zarazem prestiżową, rolę odgrywali miejscowi metysi. Tymczasem lokalni Indianie, coraz liczniej obecni w miejskiej społeczności i osiągający w niej znaczącą pozycję ekonomiczną, byli nadal spychani na margines tego ważnego wydarzenia ludycznego, zajmując w nim pozycję egzotyczno-folklorystycznego ozdobnika. Sytuacja ta z roku na rok stawała się coraz trudniejsza do zaakceptowania przez stronę tubylczą, a jej przesilenie, i to w formie ostrego konfliktu między Indianami a metysami, nastąpiło w wrześniu 1996 r., akurat w trakcie mego kolejnego tam pobytu. Ze względu na nawiązane dobre kontakty zarówno z lokalnym samorządem (metyskim), jak i miejscowymi autorytetami kiczuańskimi, mogłem uczestniczyć w debatach i negocjacjach, które miały doprowadzić do satysfakcjonującego dla obu stron rozwiązania sporu. I znów moja pozycja badacza pochodzącego „z innego świata”, nieobciążonego balastem etnicznych i rasowych uprzedzeń występujących w społeczeństwie ekwadorskim (o silnych cechach postkolonialnego kompleksu), „wtłoczyła” mnie w rolę „eksperta” i "doradcy”, od którego obie skonfliktowane strony oczekiwały "neutralnych” sugestii, pozwalających przezwyciężyć przeszkody i zachować twarz, mimo pewnych ustępstw każdej ze stron. Dla antropologa była to sytuacja niezwykle korzystna, pomimo pewnej ambiwalentności roli mediatora, bowiem umożliwiała z bliska obserwację (niejako w mikroskali) niezwykle istotnych przemian, jakie dokonywały się w Ekwadorze w ostatniej dekadzie XX w., które to, drogą silnego aktywizmu etnopolitycznego, wprowadziły zmarginalizowaną ludność tubylczą na arenę obywatelskiej sprawczości (Posern-Zieliński 2005: 151-168).

Historia przytoczona ilustruje korzystne oddziaływanie czynnika czasu, czyli koincydencji istotnego wydarzenia i momentu pobytu badacza $\mathrm{w}$ terenie. Jednak ten związek może być również dla antropologa elementem uniemożliwiającym i/lub utrudniającym realizację planowanych zadań. Przyczyny takiego stanu rzeczy mogą być różne - od wydarzeń „obiektywnych” (np. nagły wybuch rebelii, katastrofa ekologiczna czy wzmożona w rejonie aktywność partyzancka lub grup narcotraficantes) do sytuacji ",subiektywnych" wynikających z „trudnych" 
relacji w terenie (np. brak akceptacji ze strony lokalnej administracji, niechęć samorządu tubylczego, uprzedzenia miejscowych agentów zmiany). Osobiście miałem szczęście, gdyż nigdy nie doświadczyłem tego rodzaju postawy. Jednakowoż przytoczyć tu mogę przykład, pochodzący również z Ekwadoru, kiedy to antropolożka prowadząca już od kilku lat badania na południu tego kraju, w rejonie zamieszkałym przez lokalną grupę Indian Kiczua określanych mianem Saraguro, zetknęła się niespodziewanie, i to podczas kolejnego jej pobytu wśród tych społeczności, z wyraźną niechęcią większości mieszkańców (w tym także i tych dobrze jej znanych) do udzielania wywiadów i dzielenia się informacjami. Okazało się, że powodem tak nagłej zmiany nastrojów potencjalnych respondentów była aktywność na tym terenie agentów jednej z wielu działających wówczas w Ameryce Południowej cudzoziemskich organizacji pomocowych. Nie życząc sobie, by ktokolwiek z zewnątrz mógł przyglądać się bliżej ich działalności, zasiali nieufność wśród miejscowej ludności, skłaniając znaczną jej część do odmowy współpracy z antropologiem, którego zadania nie były im bliżej znane. Trzeba zauważyć, iż tego rodzaju przypadki nie należą wcale do wyjątkowych. Okazuje się bowiem, że często obecność badacza w terenie staje się niewygodna, gdyż prowadzić może w konsekwencji do opublikowania niekorzystnych informacji, do ujawnienia nagannych praktyk czy zaalarmowania opinii o działaniach nieetycznych i/lub bezprawnych?

Jak wspomniałem wyżej, antropolog może także zetknąć się z wydarzeniami całkowicie nieprzewidywalnymi, niezależnymi od jego obecności w terenie, które mogą (choć nie muszą) mieć niekorzystny wpływ na jego zamiary badawcze. Sam również, i to nie raz, doświadczyłem tego rodzaju sytuacji. Jedna z nich spotkała mnie w trakcie pobytu w La Paz (Boliwia), we wrześniu 2000 r., kiedy to po konsultacjach z tamtejszymi naukowcami przygotowywałem się do wyruszenia w "teren", aby podjąć badania w kilku społecznościach zamieszkałych przez Indian Keczua i Ajmara. Projekt przewidywał spotkania i wywiady z lokalnymi aktywistami ruchu tubylczej emancypacji, aby tym sposobem skonfrontować idee etnicznego indianizmu politycznego funkcjonujące na szczeblu centralnym z hasłami i programami głoszonymi na prowincji, a więc wśród ludności wiejskiej i małomiasteczkowej, składającej się w tym kraju przede wszystkim z populacji tubylczej.

Były to czasy wielkiego fermentu politycznego, poprzedzające demokratyczne dojście do władzy pierwszego w dziejach tego kraju prezydenta (Evo Moralesa) wywodzącego się z grupy stanowiącej większość obywateli kraju, określanej oficjalnie mianem - pueblo originarios (ludów rdzennych). Krajem wstrząsały niemal bez przerwy strajki, blokady dróg, burzliwe manifestacje, pochody protestacyjne, wiece, a działania te często paraliżowały „normalne” funkcjonowanie społeczeństwa. Wszystkie te wydarzenia, świadczące ewidentnie o tym, że Boliwia znajduje się w ciężkim kryzysie, były - i z punktu widzenia antropologa zajmującego się

7 O znaczeniu organizacji pomocowych, w działaniach na rzecz ludności tubylczej w Ameryce Południowej, piszę w pracy "Europeans and the Indigenous Peoples of Latin America” (s. 79-114), podkreślając przy tym przede wszystkim ich pozytywny wymiar, co nie oznacza, iż ta działalność nie spotyka się także z krytyką ze strony antropologów (Posern-Zieliński 2010). 
aktywizmem tubylczym - nader „korzystne”. Pozwalały bowiem na obserwację emancypacyjnych procesów, charakterystycznych dla epoki przezwyciężania postkolonialnych nierówności. Z drugiej jednak strony paraliżowały swobodę przemieszczania się po kraju, uniemożliwiając realizację zaplanowanych prac. W rezultacie coraz bardziej narastających napięć pomiędzy władzami a protestującymi Indianami, stolica Boliwii została całkowicie odcięta od reszty kraju, a także i od świata. Nieliczne drogi umożliwiające opuszczenie miasta zostały skutecznie zablokowane, co spowodowało odcięcie La Paz od lotniska (w El Alto), a także wstrzymanie strumienia codziennego zaopatrzenia w żywność napływającą z rolniczych prowincji. Tego rodzaju blokady nie były czymś wyjątkowym w boliwijskich realiach i rzec można, że mieszkańcy La Paz, a także i rząd, nauczyli się z nimi żyć i przezwyciężać różne sytuacje kryzysowe. Zazwyczaj były one tylko dramatycznym ostrzeżeniem czy też rodzajem skutecznego szantażu, który sprawiał, że po kilku dniach zwaśnione strony dochodziły do porozumienia, a drogi znów stawały się przejezdne. Jednak tym razem konflikt był szczególnie ostry i żadna ze stron nie miała zamiaru ustąpić. Dni mijały, a blokada nadal trwała, co wkrótce sprawiło, że wielkie miasto zostało pozbawione aprowizacji. Sytuacja oblężonej twierdzy wywoływała naturalny sprzeciw, prowokowała także mieszkańców miasta do coraz liczniejszych i bardziej gwałtownych protestów tłumionych brutalnie przez siły policyjne. Cudzoziemcy gremialnie opuszczali La Paz, gdyż wyjątkowo przepuszczano ich na lotnisko położone na altiplano, wysoko ponad miastem. Nie było jednak żadnej możliwości wyruszenia w głąb Boliwii ani na południe w stronę Cochabamby, ani też na północ w rejony okalające jezioro Titicaca, a więc w te rejony, w których planowałem moje kolejne pobyty badawcze. Zresztą nawet gdybym wydostał się jakimś cudem z La Paz, to i tak utknąłbym gdzieś po drodze, bowiem większość szlaków komunikacyjnych łączących stolicę z miastami we wnętrzu kraju była również skutecznie blokowana przez indiańskich chłopów, cocaleros (hodowców krzewów koki), górników i związkowców ${ }^{8}$.

W tej sytuacji musiałem elastycznie dostosować się do tych przymusowych warunków, koncentrując się na prowadzeniu wywiadów wśród aktywistów indiańskich rezydujących w mieście i reprezentujących zazwyczaj centrale różnorodnych organizacji społecznych (związkowych, chłopskich, kobiecych, rzemieślniczych, kupieckich itp.) ${ }^{9}$. Zadanie to również nastręczało sporo kłopotów, gdyż gorący czas blokady i towarzyszących jej demonstracji mocno angażował działaczy tubylczych, którzy niezbyt chętnie poświęcić chcieli swój czas na spotkania z zagranicznym antropologiem. Ponieważ blokada przedłużała się coraz bardziej i nie widać było bliskich perspektyw zakończenia kryzysu, a do tego sytuacja w mieście z dnia na dzień się pogarszała (brakowało żywności i wzrastało

\footnotetext{
${ }^{8}$ Kalendarium tych wydarzeń wraz z charakterystyką politycznych profili głównych sił tego ludowego protestu można znaleźć u Raquel Gutierrez Aguilar (2008: 99-176).

${ }^{9} \mathrm{~W}$ ten sposób wzmocniły się moje zainteresowania tubylczymi przywódcami, formowaniem się indiańskich elit oraz ich rolą w kształtowaniu się etnicznej ideologii w społecznościach rdzennych (Posern-Zieliński 2002).
} 
niebezpieczeństwo na ulicach ze względu na starcia z policją i napady), przyszło mi w końcu, i to już jako ostatniemu klientowi mojego skromnego hotelu, ewakuować się do sąsiedniego Peru. Stało się to możliwe dzięki pomocy polskiej ambasady w Limie, której obszar dyplomatycznej kompetencji obejmuje także Boliwię. Z pewnością pobyt w La Paz w trakcie blokady miasta był z punktu widzenia antropologa polityki i badacza etniczności interesującym, choć nieplanowanym doświadczeniem. Wymusił on zmianę zamierzeń oraz uniemożliwił pobyt w głębi kraju. Na szczęście rok później, w trakcie kolejnego pobytu w Boliwii, sytuacja wewnętrzna nieco się uspokoiła, pozwalając już bez zbędnych przeszkód na odwiedzenie miejscowości położonych z dala od La Paz.

\section{Konteksty badań w Chile: Mapucze i antropologia}

Po przytoczeniu tych kilku wydarzeń, w istocie niezbyt pomyślnych dla pracy antropologa, chciałbym teraz nieco bardziej wnikliwie zająć się innym przypadkiem, związanym także z pracą $\mathrm{w}$ terenie, a mającym wyraźnie znamiona tzw. „szczęśliwego trafu”. Myślę tu o nieoczekiwanym splocie okoliczności, tym razem wyjątkowo sprzyjającym badaczowi, które to w niezwykle pozytywny sposób zaważyły na przebiegu moich prac w Ameryce Południowej. Otóż po wielu sezonach badawczych (w latach 1994-2007), spędzonych w Ekwadorze, a następnie w Peru i Boliwii, w trakcie których koncentrowałem uwagę na różnych aspektach aktywizmu tubylczego oraz na strategiach emancypacyjnych indiańskich społeczności, postanowiłem kontynuować ten sam nurt badań, ale tym razem na samym południu kontynentu, a więc w Chile. Uznałem, że dla celów porównawczych, a także dla uzyskania szerszego oglądu procesów etnicznego odrodzenia, zachodzących na całym obszarze andyjskim, niezbędne jest również poznanie sytuacji ludności rdzennej w Chile. Jej zdecydowana większość to Mapucze, lud rdzenny określany w dawnej literaturze mianem Araukanów. Z lektury specjalistycznych publikacji poświęconych temu etnosowi wyłaniał się obraz Indian zdecydowanie odmienny od tego, jaki poznałem w trakcie badań prowadzonych w Andach Środkowych. Dodatkową zachętą do przeprowadzenia badań w Chile była zachodząca tam transformacja, idąca w stronę demokratyzacji i przezwyciężenia balastu autorytarnych rządów junty Pinocheta, który to proces objął również w dużym stopniu ludność tubylczą. Mapucze byli bowiem tą grupą społeczeństwa, którą również dotknęły restrykcje i prześladowania ze strony reżymu ustanowionego siłą militarnego przewrotu w roku $1973^{10}$. Zatem możliwość poznania ich sytuacji w nowych warunkach politycznych i ekonomicznych (silny neoliberalizm) była bez wątpienia również wielką zachętą. Do tego dodać należy motywację natury historyczno-symbolicznej, powiązaną z eksploratorską działalnością Ignacego Domeyki (1802-1889), znamienitego Polaka, uczonego, który w połowie XIX stulecia przemierzał ziemie zwane Araukanią, w tym czasie

${ }_{10}$ Bliższe informacje o wydarzeniach tego czasu: zob. Spyra (2013: 511-622). 
jeszcze niewłączone do „młodej” republiki chilijskiej. Plonem tej wyprawy, o charakterze zdecydowanie etnograficznym, stał się raport z roku 1845, znany pod tytułem Araukania i jej mieszkańcy (Domeyko 1992), w którym ten wybitny i wielce zasłużony dla Chile geolog zdał sprawozdanie ze swych spotkań z nadal cieszącymi się wolnością Mapuczami, i to niemal w przededniu ostatecznego utracenia przez nich niezależności ${ }^{11}$. Od czasów peregrynacji Domeyki nikt z polskiego środowiska etnologicznego, a więc przez ponad 160 lat, nie próbował pójść jego śladem i podjąć się badań wśród Mapuczy ${ }^{12}$. Dodatkowym czynnikiem zachęcającym mnie do tego, abym udał się do Araukanii, były wielkie międzynarodowe obchody 200-lecia urodzin I. Domeyki, celebrowane w 2002 r. w Chile, we Francji, na Litwie i w Polsce, w trakcie których przypomniano wielkie osiągnięcia tego badacza dla nauki (Strzałkowski 2004). Niewątpliwie te okoliczności były dla mnie także znaczącym wyzwaniem mobilizacyjnym, a jak się okazało już w trakcie badań, miały one także istotne znaczenie $\mathrm{w}$ procesie przełamywania nieufności wobec mnie wśród samych Mapuczy. Otóż dla tych, którzy byli bardziej wyedukowani, nazwisko polsko-chilijskiego eksploratora nie było obce. Choć postaci Domeyki nie łączyli z Polską, to zazwyczaj kojarzyli go jako tego, który wiele lat temu opisywał Indian z wielką sympatią. Wiedzieli, że nie przedstawiał on Araukanów światu "cywilizowanemu” jako „wojowniczych dzikusów”, ale uważał ich za przedstawicieli walecznego ludu, który pod przywództwem swych wielkich wodzów dzielnie stara się obronić swe ziemie przed chilijskimi zaborcami. Jako antropolog z Polski, a więc rodak Domeyki, a do tego przybysz $\mathrm{z}$ dalekiej Europy, która w czasach reżymu Pinocheta obdarzyła azylem wielu obywateli Chile, w tym także Mapuczy, byłem traktowany zazwyczaj ze sporą dozą zaufania, pozwalającą szybko przełamywać naturalną wstrzemięźliwość.

Chilijscy Mapucze (ich pobratymcy żyją także w Argentynie), jako potomkowie historycznych Araukanów, zamieszkują obecnie (w liczbie ok. 1.750000 osób) nie tylko na swych rdzennych ziemiach położonych w południowej części kraju (między linią rzeki Biobio a miastem Puerto Montt oraz na wyspie Chiloe), ale również w stołecznym Santiago ${ }^{13}$. Na skutek wieloletniego procesu pauperyzacji i marginalizacji oraz utraty znacznych obszarów własnych ziem, większość tej rdzennej grupy rezyduje dzisiaj z dala od swych ojczystych stron, tworząc swoistą „tubylczą diasporę" w obcym etnicznie otoczeniu ${ }^{14}$. Na terenie historycznej Araukanii, a więc na ziemiach swych przodków, Mapucze również są

11 Pierwsze wydanie tej pracy, w 1845 r., miało hiszpański tytuł: Araucania y sus habitantes, gdyż wydane zostało w Santiago de Chile; pierwsza polska edycja ukazała się w $1860 \mathrm{r}$. w Wilnie, a kolejna dopiero w 1992 r., pod redakcją i z komentarzami M. Paradowskiej i A. Krzanowskiego.

12 Próbę wędrówki po Araukanii szlakiem Domeyki podjął w 1994 r. polski latynoamerykanista J. Achmatowicz, po czym opublikował z tej podróży reportaż: zob. (Achmatowicz 2002).

${ }^{13}$ Dane te pochodzą z ostatniego spisu powszechnego z 2017 r. Wg tego źródła, opartego na autoidentyfikacyjnych kryteriach, Mapucze stanowią tylko $10 \%$ całej populacji Chile $(17,5 \mathrm{mln})$, natomiast są największą grupą tubylczą w tym kraju, bo w kategorii definiowanej jako pueblos originarios stanowią aż 80\%. (Radiografia...2018: 1-6).

${ }^{14}$ Wykorzystuję tu termin „tubylcza diaspora” zaproponowany, moim zdaniem trafnie, przez badacza Aborygenów - P. Burke (2018: 36-40), w odniesieniu do skupisk ludności rdzennej 
mniejszością, żyjąc tam w znacznym rozproszeniu pośród chilijskich mieszkańców - potomków kolonizatorów, osadników i imigrantów ${ }^{15}$. Zauważyć również należy, że w przeciwieństwie do indiańskich wieśniaków (campesinos-indigenas) z Boliwii czy Peru, nie żyją oni (w większości przypadków) w zwartych osadach, takich jak andyjskie pueblo, lecz zajmują rodzinne gospodarstwa położone zwykle na własnym skrawku ziemi, a więc w pewnym oddaleniu jedno od drugiego. Ten wzorzec osadnictwa stwarza spore kłopoty dla badacza, i to nie tylko ze względu na trudności w docieraniu do potencjalnych respondentów, ale także z powodu ograniczonych możliwości głębszego wejścia w mikroświat lokalnej społeczności.

Bardzo ważnym elementem, odróżniającym Mapuczy od pozostałych grup tubylczych rejonu andyjskiego z terenów Peru, Boliwii i Ekwadoru, jest pielęgnowana w ich środowisku pamięć historyczno-mityczna o dziejach oporu przeciwko hiszpańskim konkwistadorom, osadnikom, misjonarzom i urzędnikom. Wiedza na temat tej bohaterskiej przeszłości, wypełniona opowieściami o wybitnych wodzach, traktatach z agresorami i wygranych bataliach, w wyniku których aż do poł. XIX w. udało się Mapuczom zachować niezależność, jest wśród tej grupy Indian powszechna, i to ona kształtuje $w$ dużym stopniu ich tożsamość ${ }^{16}$. Mimo zachodzących procesów modernizacyjnych i akulturacyjnych, jest ona nadal wzmacniana silnym przywiązaniem (coraz bardziej symbolicznym) do własnego dziedzictwa kulturowego. Jego istotnym elementem (mimo migracji do miast) jest mocne przywiązanie do stron rodzinnych oraz kultywowanie przynależności klanowo-rodowej, określającej pozycję jednostki w tubylczym społeczeństwie. Zwartość etniczną tej mniejszości podtrzymują dzisiaj także ci Mapucze, którzy, zdobywszy wykształcenie, angażują się w działania na rzecz rozwoju społeczno-kulturalnego swej grupy. Wielu spośród nich to nauczyciele, naukowcy, inżynierowie, dziennikarze, prawnicy, samorządowcy, a także artyści (pisarze, rzeźbiarze, poeci). Działalność intelektualna współczesnych Mapuczy, a także pęd tubylczej młodzieży ku edukacji, jest zjawiskiem szczególnym na tle sytuacji pozostałych grup tubylczych regionu andyjskiego. Do tego dodać należy silne zaangażowanie wielu przedstawicieli tego ludu (narodu) w działalność polityczną. Ten aktywizm, uzewnętrzniony z dużą mocą w czasach demokratycznej transformacji Chile, widoczny jest w wielu formach - poczynając od zaangażowania w struktury administracyjno-samorządowe, przez działania związane z obroną zagrożonych egzystencjalnych interesów Mapuczy, a kończąc

powstających $\mathrm{w}$ wyniku wewnątrzkrajowych migracji z terenów ojczystych ku osadom i miastom społeczeństwa narodowego.

${ }^{15}$ Ok. 34\% wszystkich Mapuczy mieszka w obszarze metropolitalnym Santiago, a na rdzennych ziemiach południa Chile liczba ich oscyluje, w zależności od prowincji, między $33 \%$ a $21 \%$ miejscowej ludności (Radiografia... 2018: 7-8).

${ }^{16}$ Jednym ze źródeł tej historycznej „pamięci”, przywołującej heroiczne walki Araukanów z hiszpańskimi konkwistadorami, jest z pewnością poemat Alonso de Ercilla y Zuniga, napisany w 2 poł. XVI w. i wielokrotnie wydawany, pod tytułem La Araucana. Zarówno dla dzisiejszych Mapuczów, jak i Chilijczyków, dzieło to jest ważnym literackim upamiętnieniem bohaterów tych walk (Ercilla y Zuniga 2013). 
na tworzeniu ugrupowań o zdecydowanie etnonacjonalistycznych czy wręcz rebelianckich programach.

Trzeba zauważyć, iż wśród dzisiejszych Mapuczów dostrzec można znaczny dystans wobec nie-tubylczych Chilijczyków. Wynika on z jednej strony z uwarunkowań historycznych (relatywnie krótkiego okresu, jaki dzieli ich od czasów włączenia Araukanii w obręb Chile), z drugiej natomiast jest rezultatem bardzo złych doświadczeń tej grupy, wynikających z prowadzonej wobec Mapuczy polityki państwa. Doprowadziła ona do utraty większości ich ziem i terytoriów, spowodowała pauperyzację i marginalizację społeczną, uruchomiła migrację do miast, przyspieszyła asymilację oraz proces zaniku własnego języka (mapudungun). Ostatnie lata, mimo wprowadzania wielu reform i prób podnoszenia standardu życia ludności tubylczej, przyniosły znów wiele nowych zagrożeń, wśród których wymienić można ekspansję przemysłowej gospodarki leśnej, zastępującej dotychczasowe obszary rodzimych lasów plantacjami eukaliptusów oraz wielkie inwestycje hydroenergetyczne, które zmieniają radykalnie stosunki wodne, pogarszając drastycznie możliwości uprawy ziemi i hodowli ${ }^{17}$.

Wskazuję tu na uwarunkowania historyczne i sytuację współczesną, gdyż oba te czynniki mają istotny wpływ na kształt relacji łączących Mapuczy z nie-tubylczymi Chilijczykami. Charakteryzuje go znaczny stopień nieufności Indian wobec państwa, władzy i głównego nurtu społeczeństwa. Ponadto jest on zasilany powtarzającymi się raz po raz konfliktami, strajkami, protestami, aktami sabotażu, aresztowaniami i procesami wytaczanymi najbardziej krewkim aktywistom. Wszystkie te napięcia wzmacniają postawy etnonacjonalistyczne, szczególnie widoczne u młodych i radykalnie zorientowanych Mapuczy. Jednym z przejawów takiej postawy jest tendencja do nieutożsamiania się z państwem chilijskim, postrzeganym jako siła opresyjna. W ten sposób powstają utopijne marzenia o restytucji Wallmapu - autonomicznego terytorium obejmującego rdzenne tereny Mapuczy zarówno z chilijskiej, jak i z argentyńskiej strony.

Radykalne formy protestu przeciwko korporacjom i broniącym ich interesów siłom porządkowym (karabinierom), a także buntownicze działania sfrustrowanej młodzieży tubylczej, są naturalną pożywką dla władzy i społeczeństwa chilijskiego, ułatwiającą postrzeganie Mapuczów przez pryzmat bardzo niekorzystnych stereotypów. Przedstawiają one tych Indian jako lud wiecznie zrewoltowany, w swej tradycji historycznej wojowniczy, do tego przeciwny "postępowi” cywilizacyjnemu i modernizacji kraju, a także zagrażający integralności państwa poprzez separatystyczne skłonności i czerpanie inspiracji z etnonacjonalistycznych haseł Basków i Katalończyków. Wszystko to razem wziąwszy współtworzy w Chile atmosferę znaczącej nieufności między tymi dwoma etnospołecznymi sektorami. Taka sytuacja nie sprzyja wzajemnym relacjom, a zatem utrudnia również antropologom prowadzenie badań terenowych. Muszę przyznać, iż przed moim pierwszym pobytem w Chile niewielką miałem orientację na temat tych

${ }_{17}$ Dobrą panoramę współczesnej sytuacji Mapuczy znaleźć można w publikacjach chilijskich, np. u I. Hernandez (2003) i M. Sierra (2010), a także w monografii niemieckiej O. Kaltmeiera (2004) oraz amerykańskiej J. Crow (2013). 
wszystkich polityczno-społeczno-etnicznych kontekstów i w dużej mierze byłem przekonany, że napotkam warunki dość zbliżone do tych, w jakich prowadziłem badania terenowe w Peru czy Ekwadorze.

Tymczasem $\mathrm{w}$ trakcie badań prowadzonych $\mathrm{w}$ Araukanii ${ }^{18}$ co rusz nachodziła mnie myśl o pewnych podobieństwach między Chile a Stanami Zjednoczonymi, widocznych przede wszystkim $w$ typie relacji ludności rdzennej z państwem europejskich osadników (settler state) ${ }^{19}$. Wśród tych rzucających się w oczy zbieżności wskazać można na stanowczy zbrojny opór „Araukanów” oraz Indian z Równin i Prerii, na względnie długi okres "pokojowych" stosunków na obszarze „neutralnej" rubieży położonej między dwoma etnicznymi światami (chilijska La Frontera i amerykańska Frontier), na politykę systematycznego spychania Indian z ich ziem do specjalnych stref refugialnych (rezerwatów), na ekspansję europejskich osadników zajmujących tereny rdzennych mieszkańców, na migracje spauperyzowanych Indian do miast czy wreszcie na silny aktywizm etniczny tubylczych intelektualistów i artystów kształtujących współczesną tożsamość pueblo originarios i first people. Wymieniam w tym miejscu tylko te analogie, które wydają mi się najważniejsze, ale jest ich oczywiście znacznie więcej.

Wśród nich występuje także i ta, która ma istotne znaczenie dla antropologii, a mianowicie widoczna $\mathrm{w}$ obu krajach utrata przez tę dyscyplinę kredytu zaufania ze strony tubylczej, niezbędnego przecież w trakcie prowadzenia badań terenowych. Podobnie jak ma to miejsce w USA, również i w Chile większym poważaniem wśród ludności rdzennej cieszą się obecnie historycy (etnohistorycy) oraz prawnicy (antropologowie prawa). Jedni i drudzy postrzegani są jako użyteczni partnerzy Indian, których kompetencje mogą być pomocne w negocjacjach i procesach umożliwiających restytucję niegdyś utraconych ziem i/lub otrzymanie sprawiedliwych odszkodowań za straty spowodowane przemysłową działalnością. Na tym tle pozycja antropologa nie wygląda najlepiej, gdyż $\mathrm{w}$ wielu przypadkach kojarzony jest on z opresyjną władzą i nietolerancyjnym społeczeństwem chilijskim. Nierzadko antropologa postrzega się jako badacza, który dążąc do gruntownego poznania społeczeństwa tubylczego, czyni to po to, aby dostarczyć władzom instrumentów umożliwiających sprawowanie jeszcze większej kontroli nad nimi. Widzi się w nim także i tego, który badając indiańskie obyczaje i tradycje wzmacnia stereotypowy wizerunek Mapuczów, ukazując ich z perspektywy barwnej egzotyki i turystycznej folkloryzacji, zamiast wskazywać na ich trudne położenie i wyjaśniać naturę konfliktów z chilijskim otoczeniem (Morales Urra 1998: 297-305). W niektórych przypadkach może być

18 Przywołując w tym szkicu "Araukanię", odwołuję się do całego obszaru rdzennych ziem Mapuczów, które w ramach administracyjnego podziału Chile obejmują kilka regionów (prowincji), w tym: Biobio, Araucania (w węższym rozumieniu tej nazwy), Los Rios, Los Lagos i Aisen (Aysen).

19 Settler state to pojęcie używane w studiach nad tzw. kolonializmem osadniczym, w wyniku którego ziemie zajmowane przez ludność rdzenną są zajmowane przez populację osadników, a tubylcy eliminowani fizycznie i/lub spychani na margines. Do typowych państw klasyfikowanych tym terminem należą Stany Zjednoczone, Kanada, Australia, Nowa Zelandia, a także Chile (Veracini 2010). 
także kojarzony z użytecznym naukowym ekspertem, pracującym na rzecz przemysłowych korporacji, w celu opracowania takich raportów, których ustalenia pozwalałyby (z pozornym zachowaniem przepisów prawa) na realizację wielkich inwestycji na terenach tubylczych.

Niezależnie od tego, ile w tym niekorzystnym postrzeganiu antropologa jest uzasadnionych zarzutów, a w jakim stopniu mamy do czynienia z wyolbrzymionymi obawami, ten niekorzystny obraz musi oddziaływać na charakter wzajemnych relacji, powodując z jednej strony nieufność i wstrzemięźliwość Indian wobec badaczy, z drugiej zaś zniechęcając chilijskich antropologów do podejmowania prac terenowych wśród Mapuczy. Trzeba w tym miejscu także podkreślić, że obecnie problematyka tubylcza, a szczególnie dotycząca Mapuczy, ma silny kontekst polityczny, a to ze względu na napięte stosunki między władzą a ludnością rdzenną. Stąd też badania w tym środowisku są nierzadko czymś w rodzaju ryzykownego balansowania na linie. Bardzo łatwo można narazić się władzom, broniąc interesów Mapuczy albo też wejść w konflikt z Indianami, i to często w sposób bezwiedny, publikując rzetelne opracowania, ale zawierające treści nie w pełni satysfakcjonujące stronę tubylczą. W tak skomplikowanej sytuacji znacznie „wygodniej” jest przejść na pozycję etnohistoryka, aby z tej oddalonej czasowo perspektywy zajmować się „bezpiecznymi” tematami, takimi jak araukańsko-hiszpańskie relacje w dawnych wiekach czy funkcjonowanie ustroju wodzowskiego (cacicazgo) w czasach świetności Araukanów. Tak krytycznie wyostrzony obraz antropologii widoczny jest przede wszystkim z perspektywy stołecznej (z Santiago), a więc z naukowego i intelektualnego centrum kraju, nie tylko znacznie oddalonego od Araukanii (co najmniej 700/800 km), ale i działającego w pobliżu politycznych i finansowych ośrodków decyzyjnych.

Inaczej sprawy mają się $\mathrm{w}$ regionach zamieszkanych przez spore skupiska ludności tubylczej. W tamtejszych „prowincjonalnych” ośrodkach od wielu już lat działają antropologowie (chilijscy, europejscy, a także mapuczańscy), którzy regularnie prowadzą badania wśród grup tubylczych, nie są od nich oddaleni, znają doskonale problemy lokalne i utrzymują z nimi ciągłe i zażyłe kontakty, opierające się na wzajemnym zaufaniu. Spotkać ich można na uczelniach, w centrach badawczych, muzeach i ośrodkach monitorowania praw człowieka, w głównych miastach Araukanii: Temuco, Villarrica, Osorno i Valdivia. Co ciekawe, na tamtejszych wydziałach nauk społecznych kształci się także młodzież tubylcza, zdobywając kwalifikacje z antropologii, socjologii i interkulturowej edukacji. Niektórzy absolwenci tych kierunków, już jako profesjonalni badacze, przystępują do studiów nad własnym środowiskiem etnicznym, realizując w ten sposób postulaty dekolonizacyjnej antropologii rodzimej (antropology at home), co pozwala im nie tylko interpretować rzeczywistość społeczną „od środka”, ale także, choćby po części, spoglądać na własną grupę z pozycji emicznej (emic).

W zarysowanej wyżej sytuacji antropolog z odległego kraju znajduje się w dość ambiwalentnym położeniu. $Z$ jednej strony reprezentuje dyscyplinę niezbyt cenioną przez tubylców, z drugiej zaś nie jest wyposażony w wystarczający kapitał akceptacji, zaufania i zażyłości, którym dysponują lokalni badacze 
rezydujący w Araukanii. Odwołując się jednak do własnych doświadczeń, mogę stwierdzić, że jako badacz z innego kontynentu, a więc osoba nieobciążona bagażem chilijskiego endokolonializmu i do tego przybysz z Unii Europejskiej, cenionej ze względu na różnego rodzaju akcje solidarnościowe, programy pomocy rozwojowej, wyrazy wsparcia Mapuczy w ich dążeniach do poprawy swego losu, spotykałem się zazwyczaj, po przełamaniu wstępnej i naturalnej nieufności, z pewną ograniczoną dozą otwartości.

\section{Niespodziewane spotkanie w Araukanii i jego konsekwencje}

Zanim jednak zdałem sobie $\mathrm{w}$ pełni sprawę $\mathrm{z}$ tego, jak złożone $\mathrm{i}$ trudne jest prowadzenie badań terenowych wśród Mapuczy, postanowiłem przeprowadzić wstępne rozpoznanie sytuacji i potencjalnego obszaru przyszłych studiów, aby w kolejnym sezonie prac etnograficznych wyruszyć już do Araukanii, będąc wyposażonym w podstawową wiedzę na temat specyfiki prowadzenia studiów w tym regionie Chile. Po zakończeniu kolejnego pobytu badawczego w Peru udałem się więc, w 2007 r., do Santiago de Chile, aby odwiedzić najstarszy uniwersytet stołeczny, którego wielce cenionym do dzisiaj rektorem (w latach 1867-1883) był Ignacy Domeyko, spotkać się z miejscowymi antropologami i uzyskać od nich pożyteczne rady oraz wskazówki. Konsultacje te, szczerze mówiąc, w ograniczonym stopniu wzbogaciły moją orientację, ale dzięki nim dowiedziałem się o istniejących napięciach między antropologami a Indianami, o rosnącej wstrzemięźliwości badaczy co do dalszego prowadzenia studiów wśród Mapuczy, a także o czekających mnie potencjalnych przeszkodach w przełamywaniu nieufności Indian wobec "obcego" przybysza, nieposiadającego do tego jakiejkolwiek uwiarygodniającej rekomendacji. Poinformowano mnie także i o tym, że kontakty z tubylcami z Araukanii nie należą do łatwych, że ostatecznie są możliwe, ale wymagają dużej dozy cierpliwości i długotrwałej budowy wzajemnego zaufania ${ }^{20}$. W świetle tych uwag, z pewnością realistycznych, mój naturalny entuzjazm, związany z perspektywą podjęcia się nowych wyzwań w nieznanym dla mnie regionie Ameryki andyjskiej, zaczął wyraźnie topnieć. Tym bardziej, iż zdawałem sobie sprawę, że moje planowane pobyty na południu Chile nie będą zbyt długie (od 2 do 3 miesięcy w każdym roku realizacji projektu), a do tego przebiegać będą nie w jednej społeczności, ale co najmniej w kilku miejscach, aby w ten sposób poznać szerszy kontekst życia miejscowej ludności, zróżnicowany ze względu na odmienne cechy lokalnego środowiska. Mając te wszystkie czynniki na względzie, uzmysłowiłem sobie, że przy takim harmonogramie badań trudno mi będzie „z marszu” wejść w środowisko autochtonicznych mieszkańców i uzyskać od nich potrzebne informacje czy opinie.

${ }_{20}$ Szczególnie cenię rady i wskazówki udzielone mi przez prof. Milkę Castro Lucic, wybitną specjalistkę z zakresu antropologii prawa oraz prof. Rolfa Foerstera z Departamentu Antropologii, znawcę kultury mapuczańskiej, obydwoje z Universidad de Chile, a także znanego badacza dziejów Mapuczy - prof. Jose Bengoa z Universidad Academia de Humanismo Cristiano. 
Mimo tych niezbyt pomyślnych perspektyw, nie zaniechałem moich planów i opuściwszy Santiago, udałem się do Temuco, jednego z ważniejszych miast historycznej Araukanii. Jest ono w tym regionie ważnym centrum przemysłowym i handlowym, a także akademickim, posiadającym również placówki antropologiczne i muzeum etnograficzne ${ }^{21}$. Pod względem ludnościowym ma obecnie zdecydowany charakter wielokulturowy, z bardzo dużym udziałem potomków imigrantów z Europy i Bliskiego Wschodu. Jest także ośrodkiem przyciągającym ludność rdzenną z całej prowincji, która, opuszczając ze względów ekonomicznych swe wiejskie siedziby, przybywa coraz liczniej do Temuco. Tylko w rejonie powiatu miejskiego żyje ich już blisko 24\% (na ok. 250 tys. mieszkańców), a w samym mieście tubylcza ludność stanowi ok. 13 \% mieszkańców ${ }^{22}$. Z tego też względu jest to miasto, w którym funkcjonują liczne indiańskie organizacje, na uczelniach studiują mapuczańscy studenci, a przedstawicieli tej rdzennej mniejszości spotkać także można we władzach samorządowych.

Tak więc Temuco wydawało się dogodną bazą dla planowanych badań. Ponadto przez swe położenie przy szosie panamerykańskiej, będącej komunikacyjnym kręgosłupem Chile i zarazem całej Araukanii, umożliwiało stosunkowo dogodny dostęp do okolicznych miasteczek i rozrzuconych w interiorze osad z wiejską ludnością tubylczą. Aby z grubsza poznać ten region i ewentualnie wytypować do przyszłych badań jedną z położonych niezbyt daleko od Temuco miejscowości, pojechałem samochodem na krótki rekonesans, w trakcie którego nagle ujrzałem drogowskaz z intrygującą nazwą pobliskiej miejscowości - Chol Chol. Intuicyjnie uznałem, że najprawdopodobniej jest to toponim indiański, a zatem udając się $\mathrm{w}$ tym kierunku, trafię z pewnością na osadę zamieszkałą przez Mapuczy. Wiedziony tym impulsem znalazłem się wkrótce w centrum niewielkiego miasteczka, odległego od stolicy Araukanii ok. 30 km., którego nazwa, jako jedna z nielicznych $\mathrm{w}$ tej prowincji, wywodziła się z języka mapudungun, a więc rdzennej mowy Mapuczy. Chol Chol to po prostu „miejsce porośnięte ostami", które z biegiem lat stało się osadą i zapisało się w lokalnych dziejach jako ważny punkt na historycznej i współczesnej mapie rdzennej ludności Araukanii. Znane jest ono z wielkiego zrywu zbrojnego Indian przeciwko władzom chilijskim z 1881r., a także ze sporej aktywności etnopolitycznej jej mieszkańców; natomiast dzisiaj tworzy swoisty małomiasteczkowy mikroświat mapuczański. Około 70 \% mieszkańców tego miasteczka, liczącego 4 tys. obywateli, to Indianie, a okoliczne osady i wioski zaludnione są aż w 90\% przez ludność tubylczą ${ }^{23}$. Na ten silny indiański charakter Chol Chol wskazują przybyszowi mapuczańskie drewniane rzeźby zdobiące centralny plac, a także niewielkie muzeum etnograficzne w formie "tradycyjnej” chaty tubylczej. Krótki pobyt w tym miasteczku

${ }^{21}$ Ważnymi placówkami są: Departamento de Antropologia na Universidad Catolica, Instituto de Estudios Indigenas e Interculturales na Universidad de La Frontera, Museo Regional de la Araucania oraz Observatorio Ciudadano, założone jako Observatorio de Derechos de los Pueblos Indigenas - instytucja typu NGO nadal silnie zaangażowana w monitorowanie sytuacji Mapuczów.

22 <reportescomunales.bcn.cl/2017/index.php/Temuco/Poblacion> [dostęp 07.06.2020].

23 <reportescomunales.bcn.cl/2017/index.php/CholChol> [dostęp 08.06.2020] 
uzmysłowił mi, że powinienem rozpocząć badania właśnie w Chol Chol, jako tym miejscu, w którym, niczym w laboratorium, dostrzec można adaptację Mapuczów do warunków współczesnego życia. Przekonanie to jeszcze bardziej wzmocniły informacje o tym, że w Chol Chol działają dwie szkoły średnie, $w$ tym jedna o eksperymentalnym profilu interkulturowym, a więc dostosowanym do potrzeb młodzieży tubylczej, że funkcjonuje tam fundacja wspierająca zachowanie dziedzictwa kulturowego Mapuczów, wreszcie że we władzach lokalnych zasiadają również reprezentanci tej etnicznej społeczności.

Tak pomyślny zbieg okoliczności, który sprowadził mnie do Chol Chol, był jednak zaledwie wstępem do nieoczekiwanego spotkania, które, jak się potem okazało, miało decydujący wpływ na przebieg moich badań w Araukanii. Opuszczając to mapuczańskie miasteczko, na jego peryferiach, a w zasadzie już wśród pobliskich pól i pastwisk, napotkałem dość ubogą wiejską zagrodę, w obrębie której znajdowała się tzw. ruca, czyli jednoizbowy dom z bierwion, kryty strzechą budowla wielce charakterystyczna dla dawnej kultury Mapuczy. Współcześnie ten typ architektury tubylczej już nie występuje, chyba że wznosi się takie chaty po to, aby służyły jako symbol rdzennej kultury i miejsca zebrań Indian zasiadających wokół usytuowanego w centrum otwartego paleniska. Widok ten sprawił, że zatrzymałem samochód, a moja małżonka, która towarzyszyła mi w trakcie tego pobytu w Chile, zbliżyła się do płotu, z zamiarem wykonania kilku zdjęć. Nasza nieoczekiwana obecność w tym miejscu sprawiła, że podeszła do nas mieszkanka tej zagrody, wyraźnie niezadowolona, iż naruszamy jej prywatność. Widząc nasz samochód z miejscową rejestracją, uznała parę przybyszów za wścibskich whinka, czyli białych Chilijczyków, którzy z jednej strony traktują Indian niesprawiedliwie, a $z$ drugiej widzą $w$ nich często atrakcyjny element regionalnej specyfiki. Krótka konwersacja, w trakcie której przedstawiliśmy się jako antropologowie z Polski i osoby szczerze zainteresowane życiem Mapuczy, całkowicie odmieniła tę dość niezręczną sytuację. Już po chwili zostaliśmy zaproszeni do wnętrza ruca, aby tam w bardziej przyjaznej konwencji kontynuować rozmowę i móc bliżej się poznać. Okazało się, że nasza gospodyni - America Millaray Painemal - była osobą doskonale zorientowaną w sprawach antropologii, socjologii i historii, bowiem ukończyła studia w Związku Sowieckim. Jako córka wybitnego aktywisty mapuczańskiego o zdecydowanie lewicowych poglądach, którego spotkały poważne represje w czasach reżymu Pinocheta, uzyskała stypendium, aby w Moskwie studiować historię powszechną. Jak się okazało, w trakcie swego pobytu w ZSRR odwiedziła również Polskę i zachowała $\mathrm{z}$ tego wyjazdu pozytywne wspomnienia. W okresie demokratycznej transformacji Chile powróciła do swego kraju i zorientowawszy się, iż jej wyższe sowieckie wykształcenie w niewielkim stopniu umożliwia jej rozpoczęcie zawodowej kariery, zdecydowała się na kolejne studia. Tym razem wybrała nauki społeczne (antropologię, socjologię i "gender studies"), podjęła je w Quito (w stolicy Ekwadoru) w systemie zaocznym, uznając, że kompetencje $\mathrm{w}$ tym zakresie będą jej przydatne w działaniach na rzecz obrony interesów Indian. Była to bowiem osoba bardzo zaangażowana w różnego rodzaju akcje społeczne mające poprawić los tubylczych kobiet. W trakcie tego spotkania okazało się 
także, że America przynależy do znaczącego rodu mapuczańskiego - Painemal, którego przedstawiciele, w tym również i jej zmarły ojciec, uznani byli za osoby wielce wpływowe i cieszące się sporym autorytetem. Co ciekawe, America i jej brat (aktywista młodzieżowy, także po studiach społecznych), należeli już do drugiej generacji tubylczej inteligencji. Ich rodzice, choć zamieszkiwali w środowisku wiejskim, byli nauczycielami. To wyjątkowe spotkanie, wypełnione opowieściami o losach członków rodziny Americi, a także i o moich zamiarach badawczych, szybko uaktywniło wzajemną nić sympatii. Dodatkowym zaskoczeniem było nagłe pojawienie się studenta z USA, który przebywał u tej mapuczańskiej rodziny w ramach programu interkulturowej edukacji, promującego wśród amerykańskiej młodzieży poznawanie codziennego życia odmiennych społeczeństw, by tym sposobem budować postawy tolerancji i zrozumienia innych wartości. Sympatyczny młodzieniec, szczerze zainteresowany egzystencją Mapuczy, przede wszystkim szkolnej młodzieży, okazał się Amerykaninem polskiego pochodzenia, co nadało całemu temu nieoczekiwanemu spotkaniu wyjątkowego charakteru. Tym razem gospodyni przysłuchiwała się ze sporym zdumieniem naszej konwersacji o Polsce i Polonii, a my z ogromnym zaciekawieniem chłonęliśmy jej opowieści o losach niezwykłej tubylczej rodziny z Chol Chol.

To wyjątkowe spotkanie nie byłoby z pewnością warte tak szczegółowej relacji, gdyby nie fakt, że wówczas narodziła się idea, aby planowane badania terenowe wśród Mapuczy prowadzić z udziałem tak kompetentnej osoby, jak spotkana przypadkiem - America. Jej etniczne korzenie, kwalifikacje profesjonalne oraz głębokie osadzenie w środowisku tubylczym, pozwalały mniemać, że z jej pomocą łatwiej będzie przezwyciężyć bariery nieufności, o których wspominali antropolodzy z Santiago. Pomysł, aby zaproponować jej współudział w badaniach był dobrą decyzją, bo jak się okazało, America uczestniczyła już w kilku badaniach terenowych zleconych przez międzynarodowe organizacje pomocowe, świetnie orientowała się w bieżących problemach społecznych i regionalnych dotykających Mapuczy, w pełni świadoma była tego, że badania prowadzone wśród jej rodaków, szczególnie przez cudzoziemców, przyczynić się mogą do upowszechnienia wiedzy o trudnym położeniu tubylców w Chile i tym samym pobudzić międzynarodową solidarność na rzecz wsparcia wysiłków do poprawy ich losu. Poza tym wspomnieć należy, że America dysponowała również znaczącym kapitałem społecznym, wynikającym z jej przynależności do klanu cieszącego się w regionie Temuco powszechnym uznaniem. Pamiętano tam także o jej nieżyjącym już ojcu, jednym z aktywistów mapuczańskich, prześladowanym przez juntę Pinocheta. Te elementy biografii rodzinnej okazały się w terenie niezwykle istotne, bowiem umożliwiały szybkie nawiązywanie pożytecznych kontaktów i pozwalały na dotarcie do osób mających duże znaczenie w środowisku tubylczym. Dodatkowym czynnikiem ułatwiającym prowadzenie badań razem z Americą była sieć kontaktów wynikających z jej działalności w jednej z chilijskich organizacji kobiecych.

Wszystko to razem wziąwszy, było splotem niezwykle pomyślnych okoliczności, które doskonale wpisywały się w program moich badań. Gdy opuszczałem 
domostwo Americi, miałem już jej wstępną zgodę na udział w moich badaniach na terenie Araukanii. Zdawałem sobie sprawę, że z pomocą takiej osoby będę mógł nie tylko bardziej efektywnie docierać do interesujących mnie tubylczych działaczy, ale że ta współpraca pozwoli mi lepiej, głębiej i szybciej zrozumieć współczesną sytuację tej rdzennej mniejszości. Po zakończeniu tej wstępnej penetracji Wallmapu (czyli ziemi Mapuczy), i powrocie do Polski, nadal podtrzymywałem kontakt z Americą, zapewniając ją o tym, że jak tylko mój projekt badań w Araukanii doczeka się wsparcia finansowego, znów pojawię się w Chol Chol, aby wespół z nią poznawać realia życia „Araukanów”, 160 lat po odwiedzinach ich ziem przez Ignacego Domeykę.

I tak dzięki przypadkowemu zatrzymaniu się przy samotnej zagrodzie mapuczańskiej rodziny z Chol Chol i spotkaniu indiańskiej adeptki antropologii, mogłem ten pomyślny "terenowy przypadek" wkomponować całkiem „planowo” i intencjonalnie $w$ harmonogram kolejnego badawczego projektu. Rozpoczął się on już w następnym roku (tj. w 2008) i umożliwiał prowadzenie badań w Araukanii przez kolejne cztery sezony pobytowe, aż do roku 2011. Wspominam te lata jako okres szczególnie intensywnych penetracji ziem zamieszkałych przez Mapuczów i poznawania wielu różniących się od siebie środowisk tamtejszych Indian. Tego rodzaju mobilne badania, w swym charakterze zdecydowanie odmienne od stacjonarnego modelu, kiedy to antropolog przebywa dłuższy czas w jednej lub dwóch społecznościach, wymagały docierania do wielu miejscowości, a co za tym idzie ciągłego nawiązywania nowych kontaktów. W takiej sytuacji nie można było realizować strategii stopniowego „wrastania” w tubylcze środowisko, powolnego "oswajania” się miejscowych z przybyszem i żmudnego budowania zaufania. Należało przyjąć odmienny tryb postępowania i szukać sposobu znacznie szybszego uwiarygodniania własnej pozycji, jako osoby z odległego kraju poważnie zainteresowanej życiem i współczesnymi problemami Mapuczy. Za każdym razem trzeba więc było dostosowywać się do odmiennej wrażliwości i intelektualnego poziomu rozmówców, tak aby argumenty ukazujące cele badawcze były zrozumiałe dla strony miejscowej i mogły uruchomić oczekiwaną „otwartość" interlokutorów.

Znaczną pomoc w tym zakresie uzyskałem od Americi, która nie tylko towarzyszyła mi w badaniach terenowych, ale w sposób umiejętny organizowała niezbędne kontakty i starała się przełamywać atmosferę nieufności wobec nieznanego przybysza ${ }^{24}$. Ze względu na swe zaangażowanie społeczne $\mathrm{w}$ działalność organizacji kobiecych oraz z powodu podjętych przez nią studiów, nie zawsze mogła cały czas być $\mathrm{w}$ terenie. $\mathrm{W}$ takich sytuacjach zdarzało się, że zastępował ją jej brat - Wladimir Painemal, indiański aktywista, a także dziennikarz

${ }^{24}$ Składam w tym miejscu Americe Millaray Painemal wyrazy mojej wdzięczności za okazaną mi pomoc i owocną współpracę w czasie badań terenowych w Araukanii. Szczególnie dziękuję za Jej starania, abym mógł lepiej i głębiej zrozumieć istotne problemy współczesnego życia Mapuczów. Jestem w pełni świadomy tego, że Jej udział w tym projekcie przyczynił się wydatnie do uzyskania bardziej satysfakcjonujących rezultatów. O tym właśnie, jak ta współpraca przebiegała i jakie były jej zalety, traktuje niniejszy artykuł. 
wpływowego pisma Azkintuwe, przeznaczonego dla młodej i wykształconej generacji Mapuczy. Podstawowym celem tego periodyku było utrwalanie w tym pokoleniu tożsamości, przeciwdziałanie asymilacji i pobudzanie woli walki o równe prawa dla ludności indiańskiej ${ }^{25}$. Podczas gdy America, ze względu na swe kontakty z ramienia organizacji kobiecej, miała świetne relacje z tubylczymi mieszkankami, jej brat (którego imię w ewidentny sposób odzwierciedlało dawne komunistyczne fascynacje ich ojca) był dla mnie użytecznym przewodnikiem po świecie znaczących postaci płci męskiej. Dzięki tym sprzyjającym okolicznościom, mogłem nawiązywać kontakty zarówno z tradycyjnymi tubylczymi autorytetami wodzami (lonko) i szamankami (machi), jak i z ważnymi w regionie reprezentantami modernizującego się społeczeństwa Mapuczów (samorządowcami, burmistrzami, dziennikarzami, prawnikami, artystami). Spotykałem się także z tubylczymi intelektualistami, wykładowcami i studentami, również z młodzieżą ze szkół interkulturowych i zawodowych. Dzięki temu mogłem konfrontować przekonania wyrażane przez Mapuczy żyjących od lat w miastach z tymi opiniami, które obecne były w przekazach małorolnych chłopów (campesinos), rybaków czy drobnych rzemieślników, a więc ludzi nadal mocno osadzonych na dawnych ziemiach rodowych (wspólnotowych) (Posern-Zieliński 2012).

Duża mobilność $\mathrm{w}$ trakcie badań umożliwiła również poznanie specyfiki poszczególnych subregionów Araukanii, z których każdy w nieco inny sposób kształtował egzystencję Mapuczów. Tak więc należało dotrzeć do głównych i rozwijających się ośrodków miejskich, takich jak Temuco, Valdivia i Osorno, w których funkcjonowały instytucje i organizacje zajmujące się ludnością rdzenną, skupiające mapuczańskich intelektualistów i aktywistów. Z kolei obszary prowincjonalne i wiejskie Araukanii charakteryzowały się sporym zróżnicowaniem, w zależności od ich położenia na wschód i zachód od szosy panamerykańskiej, przecinającej Chile na dwie strefy: region andyjski i nadpacyficzny. Ten ostatni, dość trudno dostępny pod względem komunikacyjnym, okazał się obszarem typowo refugialnym, mało atrakcyjnym gospodarczo, a więc $\mathrm{w}$ dużej mierze niedoinwestowanym i relatywnie zapóźnionym $\mathrm{w}$ rozwoju. $Z$ tego też względu można tam było spotkać społeczności tubylcze bardziej izolowane, w większej mierze trzymające się „dawnego" stylu życia. Odmiennym charakterem cechował się obszar wschodni, pokryty ogromnymi jeziorami, sięgający aż do grzbietu Andów, z wieloma aktywnymi wulkanami i położonymi u ich stóp parkami narodowymi. Tereny te okazały się nie tylko atrakcyjne pod względem turystycznym, ale i gospodarczym (hodowla łososi, bydła, energetyka wodna, przemysł drzewny), co w konsekwencji mocno koliduje z interesami Mapuczy, wywołując często ostre konflikty (Posern-Zieliński 2009).

Poznanie specyfiki tych odmienności regionalnych było istotne dla realizacji projektu. Chodziło bowiem o to, aby z jednej strony móc uchwycić pewne wspólne

${ }_{25}$ Periodyk Azkintuwe (w języku mapudungun: Obserwator) został założony w 2003 r. w Temuco i wydawany był jako dwumiesięcznik do roku 2013. Jego podtytuł: „El Periodico del Pais Mapuche" sugerował, że adresowany był do Indian chilijskich i argentyńskich, i rzeczywiście docierał do czytelników mapuczańskich z obu tych krajów. 
tendencje zachodzących przemian na całym obszarze Araukanii, a z drugiej, aby mieć możliwość ukazania uwarunkowań sytuacji tamtejszej ludności, wynikających z lokalnych kontekstów. Dużym ułatwieniem w rozpoznawaniu tych wszystkich niuansów gospodarczych, etnospołecznych, interkulturowych była możliwość wspólnej pracy terenowej z mapuczańską asystentką, posiadającą dobrą orientację $\mathrm{w}$ kwestiach bieżących relacji ludności rdzennej z chilijskim społeczeństwem. Dzięki temu można było szybciej zidentyfikować bariery rozwojowe utrwalające marginalny status Mapuczy, a także poznać lokalne wysiłki na rzecz pokonywania tych przeszkód, poprzez inicjowanie (nadal skromnych) programów etnorozwojowych. Obecność takiej osoby sprzyjała zrozumieniu złożonych form mapuczańskiej tożsamości, znaczenia zasad regulujących życiem społecznym oraz przywiązania do symbolicznych przejawów kulturowego dziedzictwa. Taka współpraca ułatwiała również uchwycenie istoty nierównoprawnych relacji dotykających tubylczą mniejszość w Araukanii, które to w sytuacjach poważniejszych napięć przeradzały się w burzliwe protesty przeciwko władzy, siłom policyjnym czy wielkim korporacjom.

\section{Tubylczy partner w badaniach Mapuczów: korzyści i ograniczenia}

Warto w tym miejscu podzielić się refleksjami na temat doświadczeń wynikających ze współpracy europejskiego (polskiego) badacza z antropolożką miejscową, nie tylko wywodzącą się ze środowiska tubylczego, ale nadal mocno w nim obecną z racji prowadzonej aktywności etnicznej i społecznej. Te doświadczenia terenowe okazały się w sumie bardzo pozytywne. Nie oznaczało to jednak, że składały się one wyłącznie z zalet, gdyż w pewnych okolicznościach ujawniały się również trudności, które zresztą można było przezwyciężyć. Jednym z istotnych walorów tej współpracy w terenie „obcym” dla przybysza, a swojskim dla "tubylca”, była permanentna możliwość konfrontacji dwóch odmiennych perspektyw oraz potencjalna sposobność poznawania spojrzenia (opinii, poglądów, refleksji, ocen itp.) osoby mocno wtopionej w środowisko rdzennych mieszkańców Araukanii. Jednakże w przypadku tu omawianym należało ujmować tę tubylczą perspektywę z pewnymi uzasadnionymi zastrzeżeniami, wynikającymi bezpośrednio z zawodowej biografii Ameriki.

Po pierwsze była ona osobą wykształconą $\mathrm{w}$ zakresie nauk społecznych w Związku Sowieckim, gdzie studiowała w latach 1984-1990 i tam była poddawana odziaływaniu uproszczonego marksistowskiego ujmowania rzeczywistości, podobnie jak setki studentów zaproszonych do ZSRR z wielu krajów tzw. „trzeciego świata”. Jej lewicowe poglądy miały również korzenie rodzinne, gdyż jej ojciec wspierał chilijskich komunistów ${ }^{26}$. Kolejny etap jej edukacji przebiegał w Ekwadorze, gdzie, dzięki stypendium Forda, America podjęła w roku 2005

${ }^{26}$ F. Menares, Historiadora Millaray Painemal: „Que una mujer lidere un pais o sea de izquierda, no significa que nosotros estemos mejor" www.elciudadano.com/chile/historiadora-millaray [dostęp 10.06.2020]. 
studia na FLACSO (Facultad Latinoamericana de Ciencias Sociales), a więc na prestiżowej międzynarodowej uczelni sponsorowanej przez rządy większości krajów Ameryki Łacińskiej ${ }^{27}$. Oferowany tam profil edukacji, jak i skład kadry profesorskiej, był (jest) uformowany przez te nurty nauk społecznych, które dominują w uczelniach Ameryki Łacińskiej, Stanów Zjednoczonych i Europy. Studiujący tam przedstawiciele rdzennej ludności nabywają kompetencje charakterystyczne dla tzw. „zachodniej” nauki, a zatem ich spojrzenie na sprawy "tubylcze" ulega stopniowo znacznej modyfikacji. Natrafiamy tu na dość dobrze znany dylemat, polegający na pytaniu - na ile "tubylczy antropolog" postrzega swój świat w kategoriach współczesnych nauk społecznych, a na ile doświadcza go w ramach własnych wzorców kulturowych.

Druga kwestia, ważna w opisywanym przypadku, wynikała z bardzo mocnego zaangażowania Ameriki w działalność etnorozwojową na rzecz mapuczańskich kobiet. Była ona jedną z założycielek i prominentnych działaczek ogólnokrajowej organizacji ANAMURI (La Asociacion Nacional de Mujeres Rurales e Indigenas) ${ }^{28}$. Jednocześnie na szczeblu lokalnym, w gminie Chol Chol, przewodziła regionalnemu stowarzyszeniu mapuczańskich kobiet - „Red de Mujeres Mapuche Trawun pu Zomo". Jako aktywistka ruchu kobiecego była pod silnym wpływem zachodnich haseł feministycznych, które jednak usiłowała dostosować do andyjskiej kosmowizji i wzorców życia społecznego ${ }^{29}$. Zdecydowanie wspierała hasła ekologiczne związane z ochroną zagrożonego środowiska Araukanii (kwestia coraz bardziej skąpych zasobów wodnych) i promowała ochronę rodzimego dziedzictwa nasiennego. Jeśli dodać do tej charakterystyki bardzo negatywny stosunek Ameriki do współczesnego państwa chilijskiego, oparty na krytycznej ocenie polityki rządu wobec Indian, to możemy uznać, iż jej poglądy i spojrzenie na współczesne realia życia Mapuczy były zdecydowanie radykalne i w dużej mierze odbiegały od opinii i stanowisk wielu rdzennych mieszkańców Araukanii. Sama zresztą określała się jako „milita en Wallmapuwen" (wojowniczka na Ziemi Mapuczy). Zdając sobie sprawę z tych wszystkich nakładających się na siebie zależności, trzeba było, w trakcie badań terenowych i towarzyszących im konsultacji, starać się w miarę możliwości oddzielać opinie

\footnotetext{
27 America Millaray Painemal Morales ukończyła studia na FLACSO w 2008r., broniąc pracy magisterskiej Participacion social e identidades politicas de mujeres mapuche. El caso de ANAMURI, w której wykorzystała swe doświadczenia z działalności w ramach organizacji kobiecej ANAMURI. Zawarte tam tezy przedstawiła także w artykule: zob. Painemal 2005. W kolejnych latach zajęła się problemami dekolonizacji, dyskryminacji i rasizmu $\mathrm{w}$ Chile $\mathrm{w}$ kontekście doświadczeń kobiet tubylczych. Jako badaczka i jednocześnie Mapuczanka, współpracowała z amerykańską sociolożką i specjalistką w zakresie studiów kobiecych - P. Richards (2004) z University of Georgia nad biografiami mapuczańskich aktywistek starszego pokolenia.

28 ANAMURI to organizacja założona w 1998 r., z siedzibą w Santiago de Chile, wspierana finansowo przez europejskie NGO: „Solidaridad Suecia-America Latina”. Koordynuje ona działalność wielu lokalnych organizacji kobiecych rozproszonych po całym terytorium Chile (Sintesis 2009).

${ }_{29}$ I. Canet Caniulen y Millaray Painemal Morales, Es que Amaso demobes ser Tomas feminista? Reflexiones de mujeres mapuche para una debate, „La Linea del Fuego. Revista digital”, marzo 6, 2018, <lalineadelfuego.info/2018/03/06> [dostęp: 10.06.2020].
} 
i sądy zapośredniczone z "zachodniego" dyskursu naukowego i politycznego od tych poglądów, które wynikały z jej „autentycznego” doświadczenia tubylczego. Oczywiście dla antropologa także i ta swoista złożoność różnorodnych idei, poprzez które ujmuje się otaczający świat, jest sama w sobie również interesującym przedmiotem refleksji. Ukazuje bowiem, jak w świecie globalnym kształtowany jest światopogląd tubylczy, i jaki jest w tym procesie udział nowych, wykształconych rdzennych elit.

Szczególnie cenną pomocą w terenie okazało się wykorzystanie sieci bezpośrednich i pośrednich kontaktów, które ułatwiały szybkie oraz skuteczne docieranie do osób ważnych z punktu widzenia założeń badawczych. Liczni znajomi i członkowie rodu Ameriki, a także kojarzący ją tylko „ze słyszenia”, stawali się informatorami, którzy często udostępniali kolejne kontakty, zapewniając przy tym niezbędne rekomendacje. Tworzenie listy potencjalnych kandydatów do projektowanych wywiadów nie mogło ograniczać się tylko do sieci adresów udostępnionych przez terenowego partnera, ale było niezwykle efektywnym punktem startowym w każdej badanej miejscowości, umożliwiającym dotarcie do tych Mapuczy, których bliższe poznanie było ze wszech miar celowe. Także i w tych sytuacjach, kiedy tylko sam prowadziłem badania, lista kontaktów Ameriki okazywała się niezwykle pomocna. Ważne były wówczas uprzednie zapowiedzi (zwykle przez telefon) odwiedzin antropologa, a w przypadku braku tego rodzaju rekomendacji, zwykłe powołanie się na współpracę z Ameriką również otwierało szeroko drzwi do tubylczych domostw.

Wykorzystanie mapuczańskiej sieci kontaktów wymagało jednak wiarygodnego przedstawienia intencji i celów antropologicznej indagacji. Wspominałem już, iż istotną przeszkodą w nawiązywaniu bardziej otwartych relacji z Mapuczami była (i jest nadal) silna nieufność dzieląca ich od społeczeństwa chilijskiego - tubylcy zwykle widzą w obcych przybyszach zapowiedź nadchodzących kłopotów. Wspólna praca w terenie z Ameriką, czy innym tubylczym asystentem, pozwalała te niedogodności przezwyciężać. Już sama obecność nieznanego cudzoziemca w towarzystwie mapuczańskiej aktywistki, przedstawicielki młodego pokolenia rdzennej ludności Araukanii, stwarzała korzystną atmosferę, ułatwiającą rozpoczęcie konwersacji. Aby jednak taka wstępna rozmowa mogła niepostrzeżenie przekształcić się w wywiad, musiała ona dostarczyć argumentów trafiających do przekonania informatorów. W tym zakresie America również wykazywała się dużymi umiejętnościami perswazyjnymi, wprowadzając do dyskursu dwa rodzaje wyjaśnień. Pierwsza strategia polegała zazwyczaj na poszukiwaniu wspólnych znajomych czy dalekich krewnych, a także na podzieleniu się informacjami o pochodzeniu i miejscu zamieszkiwania jej rodu i/lub przytoczeniu pewnych faktów z dziejów owych przodków. Dla Mapuczy koneksje terytorialne i genealogiczne (przynależność jednostki do konkretnej wspólnoty, rodu i klanu) miały i nadal mają wielkie znaczenie. Tak więc tam, gdzie sieć bezpośrednich znajomości Ameriki już nie sięgała, ważne było podkreślenie jej nazwiska rodowego - Painemal oraz informacja, że gałąź tego rodu zamieszkuje region Chol Chol. Te wieści przyjmowane były zazwyczaj z akceptacją i zrozumieniem. 
Otóż okazało się, że ród Painemal odegrał znaczącą rolę w dziejach Mapuczy, bowiem jeszcze w czasach wolnej Araukanii należeli do niego wielcy wodzowie kontrolujący terytoria $\mathrm{w}$ rejonie dzisiejszego Temuco. W latach późniejszych, obejmujących dzieje niepodległej Republiki Chile, jednym z wybitnych przedstawicieli tego rodu był Don Martin Painemal Huenchal, który w poł. XX w. założył Asociacion Nacional Indigena de Chile, ważną organizację tubylczą, walczącą $\mathrm{z}$ determinacją o polepszenie losu Indian ${ }^{30}$. Dzięki swemu zaangażowaniu stał się postacią historyczną, dzisiaj szeroko znaną wśród jego rodaków. Ważnym działaczem tej organizacji był także Don Eusebio Painemal, ojciec Ameriki, z zawodu nauczyciel, sympatyk ruchu komunistycznego, represjonowany przez reżim Pinocheta, co w części społeczeństwa tubylczego przyjmowane jest nadal z szacunkiem i uznaniem ${ }^{31}$. Tak więc przywołanie tych postaci, a co najmniej wymienienie nazwy znanego powszechnie rodu, pozwalało na bardzo szybkie wykreowanie atmosfery sprzyjającej dość swobodnej wymianie myśli.

Niezależnie od argumentów odwołujących się do genealogii rodowo-politycznych, istotne były także zapewnienia Ameriki utwierdzające rozmówców o tym, że przybysz z Europy nie ma w stosunku do Mapuczy złych intencji, nie ukrywa, pod pozorem naukowych penetracji, celów mogących zaszkodzić interesom tubylczej ludności, nie jest emisariuszem władz stołecznych ani też zagranicznych korporacji rozpoznających ekonomiczne walory Araukanii. Co ciekawe, $\mathrm{w}$ przeciwieństwie do doświadczeń wyniesionych $\mathrm{z}$ prac terenowych prowadzonych w Peru, Ekwadorze czy Boliwii, gdzie zazwyczaj przedstawiciel NGO czy administracji rządowej traktowany był jako potencjalny zwiastun rozwojowych projektów, mających polepszyć los rdzennych mieszkańców, w Araukanii pojawienie się takiej osoby z reguły zapowiadało poważne kłopoty dla egzystencji Mapuczy.

Trudno im się dziwić, gdyż dotychczasowe doświadczenia związane z ekspansją wielkich korporacji (hodowlanych, leśnych, energetycznych) w pełni uzasadniały te obawy. Sam również przypadkowo spotkałem w 2011 r. taką ekipę badaczy (podających się za antropologów), którzy na zlecenie zagranicznego przedsiębiorstwa zbierali $w$ terenie informacje mające wykazać, na jakich terenach jeszcze zamieszkują Indianie, a gdzie znajdują się obszary już „wolne” od tubylców. Chodziło bowiem o to, aby mieć dokumentację, na podstawie której można by było bez zbędnych przeszkód, wynikających z formalnych przepisów ochrony mniejszości, zainicjować działalność inwestycyjną (w tym przypadku

${ }^{30}$ Biografię tego wybitnego aktywisty opracował antropolog i etnohistoryk Rolf Foerster (1983). Indianin ten umiejętnie łączył etniczne zaangażowanie na rzecz Mapuczy z działalnością polityczną w ramach partyjnych struktur chilijskich, stając się w Chol Chol i Temuco ważną postacią w Partido Democratico, ugrupowaniu założonym w 1952 r., skupiającym rolników i rzemieślników. Zob.: Grez Toso 2016; Chmara 1978.

31 Przed zamachem stanu Pinocheta w 1973 r. chilijska Partia Komunistyczna silnie infiltrowała organizacyjne struktury ruchu Mapuczy, w swych programach wspierała dążenia ludności indiańskiej do restytucji ich ziem i przywrócenia należnych im praw. Z tego też względu cieszyła się znaczną popularnością w środowisku Mapuczy. Zob. Camayos Medina i in. 2017. 
budowę elektrowni wodnej) ${ }^{32}$. Raporty takich ekip, zwykle o wątpliwej wartości, gdyż oparte na powierzchownych indagacjach lokalnych mieszkańców na temat ich tożsamości etnicznej, często z różnych powodów ukrywanej, miały służyć jako dokument uprzedzający ewentualne przyszłe roszczenia odszkodowawcze. Natomiast pojawienie się antropologa „niezależnego", współpracującego z wiarygodną osobą ze środowiska Mapuczy i głoszącego otwarcie, że jedynym jego celem jest poznanie dzisiejszej sytuacji tubylczej ludności i upowszechnienie tak zdobytej wiedzy w Europie, przyjmowane było z dużym zrozumieniem. Napomknięcie mimochodem o Ignacym Domeyce, jako o polskim pionierze badań w Araukanii, wypowiadającym się na kartach swych prac z dużą sympatią o "Araukanach”, dodatkowo wzmacniało argumenty sprzyjające zaufaniu i otwartej konwersacji. Trzeba w tym miejscu wspomnieć, iż wśród Mapuczy funkcjonuje przekonanie (wzmacniane oczywiście przez ich aktywistów), iż dla obrony ich interesów, jako zagrożonej grupy tubylczej, ważne jest upowszechnienie wiedzy na temat ich położenia w społeczeństwach o utrwalonej demokracji (takich jak USA, Kanada, Szwecja, Hiszpania, Francja i Niemcy), a więc tam, skąd zazwyczaj płynie do Mapuczy wsparcie finansowe czy logistyczne i gdzie egzystują diaspory chilijskie powstałe w wyniku politycznej emigracji po $1973 \mathrm{r}$.

Dobre rozpoczęcie spotkania, przełamanie bariery nieufności i zrozumiałe (przekonywające) dla interlokutora określenie celów rozmowy było i jest warunkiem pomyślnie przeprowadzonego wywiadu i uzyskania wartościowych informacji. W sytuacji współpracy terenowej z partnerem tubylczym przebieg sterowanego wywiadu etnograficznego zależał $\mathrm{w}$ dużym stopniu od kontekstu sytuacyjnego, treści poruszanych zagadnień, a także wieku, płci, pełnionej funkcji i orientacji ideologicznej informatora. W praktyce okazało się, że realizowaliśmy w zasadzie trzy podstawowe strategie. Pierwsza, w pełni partnerska, polegała na wspólnej (ściśle ujmując wymiennej) indagacji odwiedzanej osoby, przy czym albo na interesujące tropy, wynikające ze znajomości społeczeństwa i kultury Mapuczy, naprowadzała rozmowę America, albo sam przejmowałem inicjatywę, aby ukierunkować narrację w stronę bardziej zbliżoną do celów badawczych projektu. Drugi wzorzec wywiadu polegał na tym, że antropolożka tubylcza inicjowała rozmowę, nadając jej odpowiedni (oczekiwany przeze mnie) kierunek, a następnie oddawała inicjatywę polskiemu partnerowi, włączając się od czasu do czasu do tego dialogu, tylko po to, aby doprecyzować zadawane pytania, gdy okazywało się, że mogą one być niezbyt zrozumiałe dla informatora lub też niezręcznie sformułowane. Ten model pracy sprawdzał się doskonale i w praktyce terenowej stosowany był najczęściej.

Wreszcie trzeba wspomnieć o trzeciej wersji prowadzonych wywiadów, które okazały się dla mnie dużym zaskoczeniem. Otóż były to przeważnie rozmowy

${ }^{32}$ Jak się okazało, pracowali oni w związku z planami budowy elektrowni wodnej przez Central Hidroelectrica Maqueo na terenach położonych we wschodniej części prowincji Los Lagos w pobliżu jeziora Maihue. Już od 2007 r. inwestycja ta była silnie kontestowana przez miejscową ludność, przede wszystkim tubylczą, m.in. ze względu na obawę utraty własnych ziem oraz potencjalne szkody środowiskowe. Zob. kalendarium tego konfliktu: <proyectoconflicto. ulagos.cl> [dostęp 12.06.2020]. 
prowadzone z różnymi lokalnymi tubylczymi autorytetami (samorządowcami, aktywistami, przedstawicielami wolnych zawodów, drobnymi przedsiębiorcami itp.). W sensie formalnym inicjowała je America, aby po chwili wycofać się ze spotkania pod jakimkolwiek pretekstem i zostawić mnie samego z rozmówcą. Chodziło w tym przypadku o to, aby jej obecność (jako osoby ze środowiska tubylczego, a do tego postrzeganej przez pryzmat jej radykalnego aktywizmu etnicznego) nie miała jakiegokolwiek wpływu na otwartość i szczerość udzielanych wypowiedzi. Obawy te, jak się okazało, były w pełni uzasadnione, szczególnie gdy treść rozmowy dotykała kwestii bieżącej polityki, różnorodnych opcji ideologicznych dzielących silnie Mapuczy czy też raz akceptowanych, to znów mocno krytykowanych różnorodnych strategii tubylczego ruchu. Spotkanie i rozmowa z cudzoziemskim badaczem sam na sam była - takie odnoszę wrażenie - bardziej swobodna, mniej skrępowana, w niewielkim stopniu ograniczona „poprawnością polityczną", obawą przed odstępstwem od dominujących poglądów w środowisku informatora, czy wreszcie deklaratywnym solidaryzmem etnicznym.

Ważnym elementem współpracy terenowej były dyskusje, rozmowy, wyjaśnienia, konsultacje i komentarze, które prowadziłem z Ameriką już po zakończeniu wywiadu i powrocie do kwatery. Trzeba podkreślić, iż miały on kapitalne znaczenie, bowiem pozwalały jeszcze raz, i to na gorąco, spojrzeć na uzyskane wypowiedzi z perspektywy tubylczej, ale przefiltrowanej przez "profesjonalny" ogląd i skonfrontować je $\mathrm{z}$ "zachodnio-antropologicznym" sposobem ujmowania spraw. Dzięki tym dyskusjom sprawy niezbyt przejrzyście wyartykułowane $\mathrm{w}$ trakcie wywiadów stawały się lepiej zrozumiałe. $Z$ drugiej strony, komentarze mapuczańskiej antropolożki umożliwiały dostrzeżenie tych kwestii, które dla obcokrajowca były zazwyczaj słabo rozpoznawalne. Przykładem w tym zakresie były niektóre wypowiedzi mające bezpośredni związek z etniczną tożsamością, stosunkami interetnicznymi czy politycznym zaangażowaniem rdzennych Chilijczyków. Rozmowy na ten temat ułatwiały ujrzenie środowiska Mapuczy jako społeczności wielce zróżnicowanej pod względem wyznawanych poglądów, głoszonych opinii, czy też przejawów sympatii lub antypatii wobec władz chilijskich, jak i tubylczych ruchów protestu. Tego rodzaju komentarze nie tylko wzbogacały rozumienie treści uzyskanych informacji, były one również dodatkowym źródłem umożliwiającym poznawanie stanowiska jednego z reprezentantów nowej intelektualnej elity tubylczej. Tym sposobem antropolog tubylczy był nie tylko przewodnikiem po świecie swojej kultury, ale jako członek autochtonicznego społeczeństwa stawał się także wartościowym informatorem.

\section{Refleksje końcowe}

Moje doświadczenia terenowe pozwoliły mi zwrócić w tym tekście uwagę na dwa połączone ze sobą zjawiska, a mianowicie na rolę nieoczekiwanych spotkań (czy wydarzeń) oraz na znaczenie współpracy z tubylczym partnerem, dobrze przygotowanym do pracy w znanym mu terenie i umiejętnie wykorzystującym 
sieć swych społecznych kontaktów oraz moc posiadanych wpływów. Jeśli chodzi o pierwsze omawiane tu zjawisko, należy zauważyć, iż w relacjach wielu naukowców (niekoniecznie antropologów) pojawiają się dość często informacje o towarzyszących badaniom okolicznościach losowych, określanych mianem szczęśliwego trafu, przypadkowego odkrycia, nieprzewidzianego splotu wydarzeń. Wzmianki powołujące się na tego rodzaju "nieplanowane” okoliczności spotyka się dość rzadko na stronach raportów z badań i opracowań finalnych, gdyż zwykle skrywane są (intencjonalnie i/lub nieświadomie) pod warstwą "obiektywnych" odniesień do planowanych strategii czy zastosowanych metod postępowania. Tymczasem z szacunkowych ustaleń historyków nauki wynika, że tego rodzaju zdarzenia występowały w zdecydowanej większości doświadczeń badawczych, sięgając poziomu wahającego się od 50\% do 70\%. Najczęściej występowały one, co oczywiste, w naukach eksperymentalnych (w biologii, chemii, medycynie, farmacji), choć również odnotowywane były (co ciekawe, mniej chętnie) w humanistyce. Wspomnieć tu można choćby o niespodziewanych odkryciach zaginionych kronik i dokumentów z dawnych czasów, tkwiących przez stulecia w innych zespołach archiwalnych, czy też o nieoczekiwanych rezultatach rutynowych prac archeologicznych, w toku których nagle dochodziło do spektakularnych odkryć. Częstotliwość występowania tego typu zjawisk pozwoliła nawet na powstanie specjalistycznego pola badań nad rolą przypadków w nauce, które jest określane mianem "serendipity studies” (Hannan 2006). Studia tego typu koncentrują się nie tylko na znaczeniu zjawisk przypadkowych w naukowym postępie, ale starają się również ustalić ich relacje względem metod planowanych i przyjętych z rozmysłem metodologicznych założeń (McBirnie 2008).

Oczywiście obszar objęty refleksją "serendipity studies” nie ogranicza się tylko do wspomnianych "spektakularnych" wydarzeń, określanych mianem nieoczekiwanych "odkryć", ale obejmuje także całe spectrum różnego rodzaju okoliczności „przypadkowych”, które, ewidentnie sprzyjając podejmowanym badaniom, prowadzą je w końcu ku bardziej efektywnym rezultatom. Do tego rodzaju okoliczności zaliczyć należy niewątpliwie różne niespodziewane spotkania antropologa w terenie, które w sposób znaczący wpływają na dalszy przebieg badań. Omawiany w tym artykule przypadek ",antropologicznego spotkania interkulturowego" w Araukanii jest zapewne jednym z wielu tego typu wydarzeń, które można by było odnotować w praktyce etnograficznej, gdyby badacze $\mathrm{w}$ większej mierze dzielili się swymi doświadczeniami. Warto jednak podkreślić, że tzw. "szczęśliwy traf" nie niesie sam w sobie „wartości dodanej”. Dopiero dostrzeżenie w nim potencjału, a następnie wmontowanie takiego „przypadku” (informacji, osoby, wydarzenia) w realizowany plan badań, prowadzić może do satysfakcjonującego wyniku. W ten właśnie sposób następuje fuzja tego, co „przypadkowe" i nieplanowane, z akceptowaną $\mathrm{w}$ danej dziedzinie praktyką badawczą, realizowaną zgodnie z założonymi wzorcami naukowego postępowania. Refleksja nad tego rodzaju zjawiskami jest wprawdzie obecna w literaturze antropologicznej, ale ma dotychczas charakter rozproszony i peryferyjny. Z pewnością byłoby interesujące, i to zarówno dla samej antropologii, jak i humanistycznego 
naukoznawstwa, aby tym zagadnieniom można było poświęcić więcej uwagi i ujrzeć je nie tylko w świetle incydentalnych doświadczeń poszczególnych badaczy, ale aby spojrzeć na nie w sposób bardziej pogłębiony i wnikliwy.

Druga refleksja wynikająca z przywołanego wyżej etnograficznego doświadczenia terenowego dotyczy skutecznego sposobu przełamywania barier komunikacyjnych w trakcie interakcji badacza z jego rozmówcami. Problem ten postrzegać można co najmniej z trzech perspektyw. Pierwsza z nich, klasyczna dla antropologii, polega na tym, iż badacz stara się „zanurzyć” na bardzo długi czas w lokalnej społeczności, aby po pewnym czasie przestać być „intruzem” i stać się stałym elementem tubylczej codzienności. Ta wymagająca czasu i znacznych wyrzeczeń strategia była wielokrotnie i skutecznie stosowana, poczynając od czasów Bronisława Malinowskiego, w dużej mierze inicjatora tej metody. Zastosował ją również Wojciech Bęben, z tą jednakże różnicą, iż w trakcie wieloletnich pobytów wśród ludów Oceanii łączył działalność misyjną z aktywnością etnograficzną. Pozwoliło mu to zbudować podstawy zaufania, które - jak sam zauważył sprawiły, że „ludzie z którymi żyłem... nie okłamywali mnie, jak to czynią często w rozmowie z antropologami, mówiąc im to, co chcą [oni - AP-Z] usłyszeć..." (Bęben 2004: 12). Ta surowa ocena praktyki etnograficznej ma z pewnością w niektórych przy padkach realne podstawy. Problem oceny rzetelności uzyskiwanych informacji oraz stopnia ich celowego zniekształcania, konfabulowania czy wręcz cenzurowania przekazywanych badaczowi treści jest, i to nie od dzisiaj, dostrzegany w antropologii, choć nadal poświęca mu się - moim zdaniem - niezbyt wystarczająca uwagę. Pozostawmy jednak to zagadnienie do rozważenia przy innej okazji, gdyż wykracza ono poza ramy tego artykułu.

Innym, równie skutecznym sposobem pracy antropologa $\mathrm{w}$ terenie, jest taki, który polega na tym, że badacz żyje i pracuje zawodowo w regionie swych zainteresowań (np. w Temuco, w Cuzco czy w Otavalo) i permanentnie utrzymuje kontakty z pobliskimi środowiskami tubylczymi. Dzięki temu zdobywa niezbędne zaufanie i doprowadza do wytworzenia się stosunków „zażyłości”. W ten sposób przestaje być osobą obcą, o bliżej nieznanych intencjach, a staje się „znajomym”, któremu można powierzyć informacje o własnym świecie, mając gwarancję, że nie zostaną one wykorzystane niezgodnie z interesami badanej grupy. W wielu przypadkach takiej stałej współpracy wytwarza się specyficzna więź wzajemnych relacji i zobowiązań, prowadząca do zaangażowania się antropologa w działania pomocowe i/lub obronę zagrożonych praw tubylczych.

Gdy jednak badacz nie ma możliwości zastosowania obu tych strategii, wówczas szukać musi rozwiązań alternatywnych, pozwalających mu w trakcie krótszych pobytów, z reguły kilkumiesięcznych i powtarzanych cyklicznie przez kilka lat, zbudować atmosferę sprzyjającą pozyskiwaniu poszukiwanych danych. Z pewnością jednym ze skutecznych sposobów postępowania jest przedstawiony $\mathrm{w}$ tym szkicu przykład prowadzenia badań terenowych przy współpracy tubylczego partnera i/lub asystenta. Udział takiej osoby w projekcie nie gwarantuje automatycznie sukcesu badawczego, ale z pewnością może mieć w nim istotny udział. Jest przecież taki partner potencjalnie kompetentnym 
przewodnikiem po tubylczym świecie, a jeśli posiada do tego kwalifikacje antropologiczne (lub pokrewne), to staje się nie tylko kulturowym translatorem, ale także użytecznym interpretatorem własnej kultury. Moja relacja z araukańskich doświadczeń badawczych była refleksją o takiej współpracy, która narodziwszy się przypadkiem, stała się formą przyjętej strategii, pokazała skuteczność tego rodzaju praktyki. Sądzę, że taki model kooperacji powinien zyskać większą popularność. Zauważmy bowiem, że wraz ze wzrostem poziomu edukacji wśród ludności rdzennej, wraz z coraz większą popularnością uczelni interkulturowych kształcących młodzież indiańską, także w zakresie nauk społecznych (w tym i antropologii), zwiększa się możliwość prowadzenia badań przez specjalistów z krajów europejskich w towarzystwie kompetentnych partnerów tubylczych. Taka wspólna praca w terenie jest i będzie zawsze szczególnym doświadczeniem nie tylko badawczym, ale również egzystencjalnym, wynikającym ze spotkania dwóch antropologów, wprawdzie posługujących się pozornie podobnymi konceptami, ale jednocześnie przynależących do odmiennych światów i postrzegających przedmiot wspólnych zainteresowań z odmiennych perspektyw.

\section{Literatura}

Achmatowicz, J. (2002). Por las huellas de Domeyko. "Araucania y sus habitantes" de Ignatio Domeyko - 150 años despues. Santiago de Chile: Ed. Unión Polaca en Chile.

Bęben, W. (2004). Mały świat wokót wulkanu. Tradycyjne normy zwyczajowe w życiu wyspiarzy Biem w Papui Nowej Gwinei. Warszawa: Wydawnictwo DiG.

Bęben, W. (2006). Dzieci kazuara. Lublin: Wydawnictwo Gaudinum.

Burke, P. (2018). An Australian Indigenous Diaspora. New York-Oxford: Berghahn.

Campos Medina, J., Farias Duran, C., Vergara Pinto, F. (2017). Aproximacion a la identidad etnica mapuche dentro del Movimiento Campesino Revolucionario. Izquierdas, 37, 120-141.

Chmara, M. (1978). Klasy społeczne i partie polityczne Republiki Chile: 1969-1973. Warszawa: PWN.

Crow, J. (2013). The Mapuche in Modern Chile. A Cultural History. Gainesville: University Press of Florida.

Domeyko, I. (1992) [1860]. Araukania i jej mieszkańcy. Warszawa-Kraków: Polskie Towarzystwo Studiów Latynoamerykanistycznych.

Ercilla y Zuniga, A. (2013) [1569]. Araukana. Przeł. Cz. Ratka. Gliwice: Wyd. Czesław Ratka.

Foerster, R. (1983). Martin Painemal Huenchal. Vida de un dirigente mapuche. Santiago de Chile: Ed. Academia de Humanismo Cristiano.

Grez Toso, S. (2016). El Partido Democratico de Chile. Santiago de Chile: Ed. LOM.

Gutierrez Aguilar, R. (2008). Los ritmos del Pachacuti. Movilización y levantamiento indigena- popular en Bolivia. Buenos Aires: Ed. Tinta Limon.

Hannan, P. (2006). Serendipity. Luck and Wisdom in Research. Lincoln: Ed. Universe.

Hernandez, I. (2003). Autonomia o ciudadania incompleta. El Pueblo Mapuche en Chile y Argentina. Santiago de Chile: Pehuen Ed.

Kaltmeier, O. (2004). Marichiweu! - Zehnmahl werden wir siegen!. Eine Rekonstruktion der aktuellen Mapuche-Bewegung in Chile aus der Dialektik von Herrschaft und Widerstandseit der Conquista. Münster: Ed.ITP. 
Malinowski, B. (1981) [1922]. Argonauci zachodniego Pacyfiku. W: Malinowski, B., Dzieła, t. 3. Warszawa: PWN.

McBirnie, A. (2008). Seeking serendipity: the paradox of control. Aslib Proceedings. New Information Perspectives, 60, 6, 600-618.

Morales Urra, R. (1998). Los Mapuche escritos por antropologos chilenos: Un caso de autorias anonimas. Actas del III Congreso Chileno de Antropologia, Temuco, 1, 297-305.

Posern-Zieliński, A. (1982). Tradycja a etniczność. Przemiany kultury Polonii amerykańskiej. Wrocław: Ossolineum.

Posern-Zieliński, A. (2002).Przywódcy indiańscy w krajach andyjskich i ich rola w konsolidacji ruchu tubylczego. W: J. Derlicki, W. Lipiński (red.), Pierwsze narody. Społeczności rdzenne i idea tubylczości we wspótczesnym świecie (s. 179-196). Warszawa: Wydawnictwo DiG.

Posern-Zieliński, A. (2003). Między konfliktem a wzmocnieniem. Religia a etniczność w doświadczeniu Polonii amerykańskiej W: Posern-Zieliński, A. (red.), Etniczność a religia (s. 49-62). Poznań: Wydawnictwo Poznańskie.

Posern-Zieliński, A. (2005). Między indygenizmem a indianizmem. Andyjscy Indianie na drodze do etnorozwoju. Poznań: Wydawnictwo Naukowe UAM.

Posern-Zieliński, A. (2009). El pueblo mapuche frente al estado chileno. El nuevo activismo indigena en la epoca de la globalización. Estudios Latinoamericanos, 29, 9-26.

Posern-Zieliński, A. (2010). Europeans and the Indigenous Peoples of Latin America. W: Stemplowski. R. (ed.), Europe and Latin America - Looking at Each Other? (s. 79-114). Warszawa: Polski Instytut Spraw Międzynarodowych.

Posern-Zieliński, A. (2012). The Mapuche from Araucania. Their Identity, Ethnic activism, and Attitudes toward the State. Ethnologia Polona, 31-32, 191-205.

Radiografia de genero (2018). Radiografia de genero. Pueblos originarios en Chile. Santiago: Instituto Nacional de Censos.

Richards, P. (2004). Pobladoras, Indigenas and the State: Conflicts over Women's Rights in Chile. New Brunswick, N.J.: Rutgers University Press.

Sierra, M. (2010). Un pueblo sin estado. Mapuche - gente de la tierra. Santiago de Chile: Ed. Catalonia.

Sintesis...(2009). Sintesis: Primer Congreso Nacional ANAMURI. Santiago de Chile.

Spyra, J. (2013). Chile. Warszawa: Wydawnictwo Trio.

Strzałkowski, A. (red.) (2004). Ignacy Domeyko w 200 rocznicę urodzin. Kraków: PAU.

Veracini, L. (2010). Settler Colonialism: A Theoretical Overview. Palgrave, Hampshire: Palgrave.

\section{SUMMARY}

Serendipitous chance and a native partner: Some anthropological experiences from fieldwork in the U.S. and South America

The main theme of this essay is twofold: 1 . the role of unforeseen, unplanned events and encounters that usually take place in the course of ethnographic fieldwork, and 2. the advantages and disadvantages of fieldwork collaboration with an indigenous partner/assistant, combining his/her competences in local matters with that in social sciences. These reflections are based on the author's experiences from research carried out in the U.S., focusing on the Polish-American diaspora and from studies conducted 
among indigenous communities of the Andean America. The cases discussed are related to the situation in Ecuador and Bolivia, and above all Chile, where the author carried out his fieldwork in the area of Araucania, the native land of Mapuche.

Keywords: ethnographic fieldwork, native collaborator, serendipity, USA, Polish Americans, Ecuador, Bolivia, Chile, Araucania, Mapuche 